\title{
Thermodynamic Constraints on Smectite and Iron Oxide Formation at Gale Crater, Mars: Insights into Potential Free Energy from Aerobic Fe Oxidation in Lake Water-Groundwater Mixing Zone
}

\author{
Sakiko Kikuchi * and Takazo Shibuya
}

check for updates

Citation: Kikuchi, S.; Shibuya, T. Thermodynamic Constraints on Smectite and Iron Oxide Formation at Gale Crater, Mars: Insights into Potential Free Energy from Aerobic Fe Oxidation in Lake Water-Groundwater Mixing Zone. Minerals 2021, 11, 341. https:// doi.org/10.3390/min11040341

Received: 29 January 2021

Accepted: 22 March 2021

Published: 25 March 2021

Publisher's Note: MDPI stays neutral with regard to jurisdictional claims in published maps and institutional affiliations.

Copyright: (c) 2021 by the authors. Licensee MDPI, Basel, Switzerland. This article is an open access article distributed under the terms and conditions of the Creative Commons Attribution (CC BY) license (https:// creativecommons.org/licenses/by/ $4.0 /)$.
Super-Cutting-Edge Grand and Advanced Research (SUGAR) Program, Institute for Extra-Cutting-Edge Science and Technology Avant-Garde Research (X-Star), Japan Agency for Marine-Earth Science and

Technology (JAMSTEC), Yokosuka 237-0061, Japan; takazos@jamstec.go.jp

* Correspondence: skikuchi@jamstec.go.jp

\begin{abstract}
The presence of saponite and iron oxides in Sheepbed mudstone of Yellowknife Bay at Gale crater on Mars is considered as evidence of a habitable fluvio-lacustrine environment for chemolithoautotrophy. However, the energetic availability for metabolic reactions is poorly constrained. Herein, we propose the possible mixing of surface water and groundwater that (i) explains the formation of magnetite and hematite detected in Sheepbed mudstone and (ii) may work as a potential habitable zone for aerobic $\mathrm{Fe}^{2+}$-oxidizing microbes. Our thermodynamic modeling of water-rock reactions revealed that the formation of abundant saponite in Sheepbed mudstone may occur under various conditions of water-to-rock mass ratios, temperatures $\left(5-200^{\circ} \mathrm{C}\right)$, and initial fluid compositions. In contrast, the formation of iron oxides in the mudstone can be explained only by the mixing of $\mathrm{Fe}^{2+}$-rich groundwater and more oxidized surface waters, where the $\mathrm{Fe}^{2+}$-rich groundwater can be generated by the low-temperature water-rock reactions with a $\mathrm{CO}_{2}$-bearing initial fluid. The calculated bioavailable energy of aerobic $\mathrm{Fe}^{2+}$ oxidation in the fluid-mixing zone on Mars is similar to that estimated for a fluid-mixing zone on Earth actually inhabited by aerobic $\mathrm{Fe}^{2+}$-oxidizing microbes. The findings will contribute to a better understanding of potential habitability on Mars.
\end{abstract}

Keywords: early Mars; Gale crater; water-rock reactions; Fe oxide; Fe-oxidizing microbe; saponite; bioavailable energy; fluid-mixing zone

\section{Introduction}

The search for microbial life on Mars-both past and present-is of significant interest in astrobiological research. In this regard, the identification of former presence of liquid water, which is a fundamental requirement for any known life, advanced our understanding about the potential habitability on Mars. The representative evidence of liquid water is the fluvial systems and the widespread presence of clay minerals in Noachian terrains. This evidence was obtained from geological, geochemical, and geomorphological analyses based on orbiting spacecraft [1,2]. On the ground on Mars, in contrast, the Mars Science Laboratory Rover Curiosity still conducts chemical and mineralogical analyses of various section of fluvio-lacustrine strata in Gale crater, and continuously provides further details about the water chemistry of ancient lakes and/or groundwater (e.g., neutral pH, low salinity, and redox-stratified water) [3,4]. Furthermore, the presence of bioessential elements such as phosphate, sulfur, and nitrogen as well as carbon compounds were detected from the sediments $[5,6]$. The evidence suggests that early Mars had environments favorable for microbial lives $[3,4]$.

Concomitant with these explorations of Mars, microbial metabolisms favorable considering the geochemical gradients available on Mars were also proposed [7]. Examples are $\mathrm{Fe}^{2+}$-oxidizing microbes [8], methanogens [9], sulfur-oxidizing microbes [10], and 
halophilic CO metabolizing microbes [11]. These considerations are mainly based on the microbial analyses of Mars-like terrestrial analog sites such as fluvio-lacustrine systems $[12,13]$ and acidic environments [14]. Laboratory-based culturing experiments were also conducted under simulated Mars conditions $[15,16]$. These studies suggest the possibility of diverse metabolic reactions of microbial life on Mars.

Nevertheless, it is still uncertain whether the proposed microorganisms could gain energy in Gale crater on Mars. One of the main reasons for this uncertainty is the lack of quantitative water chemistry (e.g., lake water and groundwater), including the concentrations of specific elements (e.g., $\mathrm{Fe}^{2+}, \mathrm{H}_{2}$, and $\mathrm{O}_{2}$ ) that can be used for microbial metabolic reactions. In this regard, a recent study reconstructed the possible solution compositions (e.g., $\mathrm{Na}^{+}, \mathrm{K}^{+}, \mathrm{Mg}^{2+}, \mathrm{Cl}^{-}$, and $\mathrm{Fe}^{2+}$ ) of pore water in mudstone in Yellowknife Bay [17]. However, no works have quantitatively considered the water environments that generated a geologically sustainable chemical disequilibrium that is available for microbial metabolism. In contrast, in terrestrial settings where the chemical compositions of fluids (e.g., seawater, hydrothermal water, and groundwater) are well characterized, the calculations of free energy distribution in the water-mixing zone are a powerful tool to predict microbial abundances in the ecosystems [18-20]. Further, the estimated free energies on Earth are well consistent with the actual microbial communities estimated from DNA analyses [21,22]. Therefore, the thermodynamic estimation of various water compositions and the bioavailable energies in the fluid-mixing zone can be used for assessing whether there were energetically habitable environments on ancient Mars.

In this work, we propose the presence of a mixing zone between surface water and groundwater, which can explain the mineral assemblage of sediments observed in Gale crater and the potential habitability of the mixing zone. Our work is based on the waterrock reaction modeling and Gibbs free energy calculations. Sheepbed mudstone of Yellowknife Bay in Gale crater was considered as one of the representative areas to reconstruct an ancient lacustrine and habitable environment [3]. It is the first set of mudstones analyzed by Curiosity rover, and two drill samples (John Klein and Cumberland) collected from the mudstone provide a wealth of information about the mineralogical and compositional data of the ancient mudstone $[3,5,23]$. The mudstone has a basaltic bulk composition and consists of detrital mafic minerals, calcium sulfates, iron (hydr)oxides, trioctahedral smectites, and amorphous materials [5]. The most characteristic feature of Sheepbed mudstone is that it contains $\sim 20 \mathrm{wt} \%$ of trioctahedral smectite and $\sim 4.4 \mathrm{wt} \%$ magnetite- these contents are higher than those detected in nearby eolian deposits [5]. Therefore, we aimed to constrain the formation conditions of the smectite and magnetite (also hematite) and to assess the bioavailable energy based on the thermodynamically estimated compositions of various waters flowing into Gale crater. In the energy calculations, we evaluated the Gibbs free energy of aerobic $\mathrm{Fe}^{2+}$ oxidation that was previously suggested for the Yellowknife Bay water environment [24].

\section{Initial Conditions}

\subsection{Initial Rock Composition}

Table 1 lists the chemical composition of the initial rock used in the thermodynamic calculations. The contents of $\mathrm{Si}, \mathrm{Al}, \mathrm{Fe}, \mathrm{Mg}, \mathrm{Ca}, \mathrm{Na}$, and $\mathrm{K}$ were obtained from the mean composition of Darwin-type conglomerates in Gale crater, which are considered to be the average composition of the igneous crust at Gale crater [25]. $\mathrm{Cl}$ and $\mathrm{S}$ were obtained from a Darwin-type conglomerate named "Burdin_Bluffs2_pebble", since this rock is dust-free, and thus represents a more realistic composition of $\mathrm{S}$ and $\mathrm{Cl}$ in conglomerates [25]. The $\mathrm{S}$ (recalculated from $\mathrm{SO}_{3}$ ) and $\mathrm{Cl}$ compositions are $1.79 \mathrm{wt} \%$ and $1.46 \mathrm{wt} \%$, respectively. The oxygen fugacity $\left(f \mathrm{O}_{2}\right)$ that enables the rock to contain $1.79 \mathrm{wt} \%$ of $\mathrm{S}$ in basaltic melts is two units above fayalite-magnetite-quartz oxygen buffer line [26], and $\mathrm{S}$ is mainly present as $\mathrm{SO}_{2}$ gas in this $f \mathrm{O}_{2}$ [27]. We therefore recalculated the reported $\mathrm{SO}_{3}$ values as $\mathrm{SO}_{2}$ and used it as the initial composition. In the case of $\mathrm{Cl}$, it is usually present in the basaltic melt and degases as $\mathrm{HCl}$ [28]. We therefore set $\mathrm{HCl}$ as the initial phase (Table 1). 
Table 1. Chemical composition of the rock used in the modeling, as created based on the composition of Darwin-type conglomerates in Gale crater [25].

\begin{tabular}{cccccccccc}
\hline $\mathrm{SiO}_{2}$ & $\mathrm{Al}_{2} \mathrm{O}_{3}$ & $\mathrm{FeO}$ & $\mathrm{MgO}$ & $\mathrm{CaO}$ & $\mathrm{Na}_{2} \mathrm{O}$ & $\mathrm{K}_{2} \mathrm{O}$ & $\mathrm{SO}_{2}$ & $\mathrm{HCl}$ & Total \\
\hline 49.34 & 13.15 & 15.45 & 5.66 & 6.72 & 3.94 & 0.86 & 3.44 & 1.44 & 100 \\
\hline
\end{tabular}

\subsection{Initial Fluid Composition}

We assumed that the ancient lake present in Gale crater was maintained by two water sources: river water and groundwater. Both types of water are considered to originate from rainfall and then chemically evolve through water-rock reactions.

In the case of water-rock reactions that control river water chemistry, we set two types of initial fluids (Case I and Case II, Table 2). Each fluid reflects different gas-bearing water, simulating two types of different atmospheric conditions that perhaps prevailed on early Mars. In both cases, the total pressure was fixed as 1.0 bar, based on a previous estimation that the atmospheric pressure at $4.0 \mathrm{Ga}$ was around 1 bar on Mars [29]. Additionally, we hypothesized that early Mars had a $\mathrm{CO}_{2}$-dominated atmosphere [30], which is similar to the present-day condition [31]. In addition to these assumptions, we considered $0.002 \mathrm{bar}$ of $\mathrm{O}_{2}$ and 0.100 bar of $\mathrm{H}_{2}$ in both cases to represent $\mathrm{O}_{2}$-bearing initial fluid and $\mathrm{H}_{2}$ bearing initial fluid, respectively. The partial pressure of $\mathrm{O}_{2}\left(p \mathrm{O}_{2}\right)$ was estimated from the presence of $\mathrm{MnO}_{2}$ in sedimentary rocks in Gale crater to be greater than or equal to $\sim 2$ mbar [32]. Therefore, we tentatively set 2 mbar of $p \mathrm{O}_{2}$ as a possible oxidant present on early Mars, although the $p \mathrm{O}_{2}$ estimated from the formation conditions of $\mathrm{MnO}_{2}$ includes large uncertainties such as formation temperatures, coexisting elements, and the presence of other oxidants (e.g., perchlorates and nitrate) [32,33]. In contrast, the partial pressure of $\mathrm{H}_{2}\left(\mathrm{pH}_{2}\right)$ is based on the finding that the sole presence of $\mathrm{CO}_{2}$ is not enough for liquid water to exist in a stable state and other greenhouse gasses such as $\mathrm{H}_{2}$ (ca. $10 \%$ in the case of total pressure of 1 bar) is required [34]. An important feature of the water-rock reactions in the river, as well as its fundamental difference with the subsurface water-rock reactions, is that gas can be exchanged during the water-rock reactions. To reproduce this condition, the gas fugacities of $\mathrm{CO}_{2}, \mathrm{O}_{2}$, and $\mathrm{H}_{2}$ were fixed at the initial value during the thermodynamic modeling of water-rock reactions (Table 2). The initial fluid temperature was fixed as $5^{\circ} \mathrm{C}$ based on the assumption that early Mars had a cold environment [35].

Table 2. Initial fluid parameters used in the thermodynamic modeling. Two types of initial fluids (Case I-R, and II-R) are considered for river water, whereas three types of fluids (Case I-SG, II-SG, and III-DG) are considered for groundwater.

\begin{tabular}{|c|c|c|c|c|c|c|}
\hline Case & Initial Fluid & Type of Water & $\begin{array}{c}\text { Gas Exchange } \\
\text { during Water-Rock } \\
\text { Reactions }\end{array}$ & $\begin{array}{c}\text { Temperature } \\
\left({ }^{\circ} \mathrm{C}\right)\end{array}$ & Case Code & Note \\
\hline \multirow[b]{2}{*}{ I } & \multirow{2}{*}{$\begin{array}{c}\mathrm{O}_{2} \text {-bearing water } \\
\left(\mathrm{O}_{2} 0.002 \text { bar }+\mathrm{CO}_{2}\right. \\
0.998 \text { bar })\end{array}$} & River water & YES & 5 & $\mathrm{I}-\mathrm{R}$ & \multirow[b]{2}{*}{$\begin{array}{l}\text { Simulating shallow } \\
\text { groundwater }\end{array}$} \\
\hline & & Groundwater & NO & $5,25,100,200$ & I-SG & \\
\hline \multirow[b]{2}{*}{ II } & \multirow{2}{*}{$\begin{array}{c}\mathrm{H}_{2} \text {-bearing water } \\
\left(\mathrm{H}_{2} 0.1 \mathrm{bar}+\mathrm{CO}_{2}\right. \\
0.9 \text { bar })\end{array}$} & River water & YES & 5 & II-R & \multirow[b]{2}{*}{$\begin{array}{l}\text { Simulating shallow } \\
\text { groundwater }\end{array}$} \\
\hline & & Groundwater & NO & $5,25,100,200$ & II-SG & \\
\hline III & Gas free water & Groundwater & NO & $5,25,100,200$ & III-DG & $\begin{array}{l}\text { Simulating deep } \\
\text { groundwater }\end{array}$ \\
\hline
\end{tabular}

In the case of the water-rock reactions that control groundwater chemistry and subsurface secondary mineral assemblage, we set one more type of initial fluid (Case III in Table 2) in addition to Case I and Case II. Case I and Case II represent the $\mathrm{O}_{2}$-bearing and $\mathrm{H}_{2}$-bearing initial fluids, respectively, where the $p \mathrm{O}_{2}$ and $p \mathrm{H}_{2}$ are the same as those explained previously. Fluids infiltrating into the surface of the rock contain atmospheric gas, and therefore Case I and Case II represent groundwater and secondary mineral assemblage in the shallow subsurface zone. In the case of fluid that percolates through the deeper subsurface, however, the composition of the initial fluid may differ from that of 
shallow fluids because the gas can be consumed by mineral precipitation. We considered gas-free water with a $\mathrm{pH}$ of 7 in Case III. In the case of subsurface water-rock reactions, post-impact hydrothermal activity could increase the temperature of the initial fluid [36]. Although such hydrothermal activities have not been suggested for Yellowknife Bay, we assumed 5, 25, 100, and $200{ }^{\circ} \mathrm{C}$ for initial fluid temperatures to consider the possible effect of hydrothermal activities in Gale crater.

\section{Modeling Method}

The thermodynamic water-rock reaction modeling was conducted using software package EQ3/6, version 8.0 [37]. The thermodynamic database required for the calculations was assembled using SUPCRT92 [38], which comprises thermodynamic data for minerals, aqueous species, and complexes taken from previous works [39-43], and calculated using the estimation techniques of Wilson et al. (2006) [44]. Activity coefficients of dissolved inorganic species were calculated using the B-dot activity model, while the activity coefficients were assumed to be unity for neutral aqueous and gaseous species, except for those for $\mathrm{CO}_{2}$. The temperature-dependent activity coefficient for $\mathrm{CO}_{2}$ was taken from the empirical relationship [45]. The solid solution in the model included carbonate (magnesite-calcite-siderite), serpentine (chrysotile-greenalite), and Mg-Fe substitution for all saponite (saponites including in $\mathrm{Na}, \mathrm{K}, \mathrm{Ca}, \mathrm{Mg}$, and $\mathrm{Fe}$ in the layer). The details of secondary minerals and amorphous phases considered in the thermodynamic reactions are listed in Table A1 in Appendix A. Note that the formation of chlorite was suppressed in our calculation because the formation of chlorite and saponite appears competitive while the formation of chlorite is kinetically much slower than saponite especially at low temperatures [46].

Mineral-fluid equilibria at each temperature with each initial fluid was calculated at a water-to-rock mass ratio (W/R) of 0.1-5000. Each thermodynamic modeling consists of three steps. First, $1 \mathrm{~kg}$ of initial fluid $\left(\mathrm{O}_{2}\right.$-bearing, $\mathrm{H}_{2}$-bearing, or gas-free fluid) is specified at $25{ }^{\circ} \mathrm{C}$. In the second step, the initial fluid is heated or cooled to the desired temperature. The solid reactants, up to a maximum amount of $10 \mathrm{~kg}(\mathrm{~W} / \mathrm{R}=0.1)$, are added in increments to the fluid at the fixed temperature, while the equilibrium between fluid and rock is calculated in each increment.

The bioavailable free energy of aerobic $\mathrm{Fe}^{2+}$ oxidation in the fluid-mixing zone was determined by considering the following $\mathrm{Fe}^{2+}$ oxidation reactions

$$
\begin{gathered}
\mathrm{Fe}^{2+}+0.25 \mathrm{O}_{2}+1.5 \mathrm{H}_{2} \mathrm{O} \rightarrow \mathrm{FeOOH} \text { (goethite) }+2 \mathrm{H}^{+} \\
3 \mathrm{Fe}^{2+}+0.5 \mathrm{O}_{2}+3 \mathrm{H}_{2} \mathrm{O} \rightarrow \mathrm{Fe}_{3} \mathrm{O}_{4} \text { (magnetite) }+6 \mathrm{H}^{+}
\end{gathered}
$$

and calculating the Gibbs free energy $\left(\Delta \mathrm{G}_{r}\right)$ of each of the reactions as follows:

$$
\Delta \mathrm{G}_{r}=\Delta \mathrm{G}_{r}^{\circ}+R T \ln Q_{r}
$$

where $\Delta \mathrm{G}_{r}{ }^{\circ}, R, T, Q$ are standard free energy, universal gas constant, temperature $(\mathrm{K})$, and activity quotient of the compounds involved in the reaction. The values of the standard Gibbs energy $\left(\Delta \mathrm{G}_{r}{ }^{\circ}\right)$ for the redox reaction were calculated by SUPCRT 92 [38] with a customized thermodynamic database described above. The free energy per kilogram of mixed fluid was obtained by multiplying the $\Delta \mathrm{G}_{r}$ obtained from the reaction by the concentration of the limiting reactant, taking reaction stoichiometry into account. We also calculated the free energy per kilogram of groundwater by multiplying energy $/ \mathrm{kg}$ of the mixed fluid by the total amount of mixed fluid. 


\section{Results and Discussion}

\subsection{River Water Chemistry and Secondary Mineral Assemblage \\ 4.1.1. Models with $\mathrm{O}_{2}$-Bearing Fluid (Case I-R)}

When the rock reacted with $\mathrm{O}_{2}$-bearing initial fluid under gas exchangeable conditions, nontronite, kaolinite, and quartz are suggested as the dominant secondary phases for all the modeled W/R (Figure 1a). In addition, carbonate formation is suggested at W/R between 0.1 and 100; magnesite and calcite are the dominant carbonate solid solution at $\mathrm{W} / \mathrm{R}$ between 0.1 and 1.6, whereas calcite dominated the carbonate solid solution at $\mathrm{W} / \mathrm{R}>$ 1.6. Nontronite $\left(\mathrm{Fe}^{3+}\right.$ smectite) is considered as the main sink of Fe. Note that quartz can be replaced by amorphous $\mathrm{SiO}_{2}$ (or other $\mathrm{SiO}_{2}$-rich phyllosilicate) if quartz formation is suppressed. However, the differences in $\mathrm{SiO}_{2}$-rich materials do not largely influence the fluid compositions.

\section{(a) $\mathrm{O}_{2}$-bearing initial fluid}
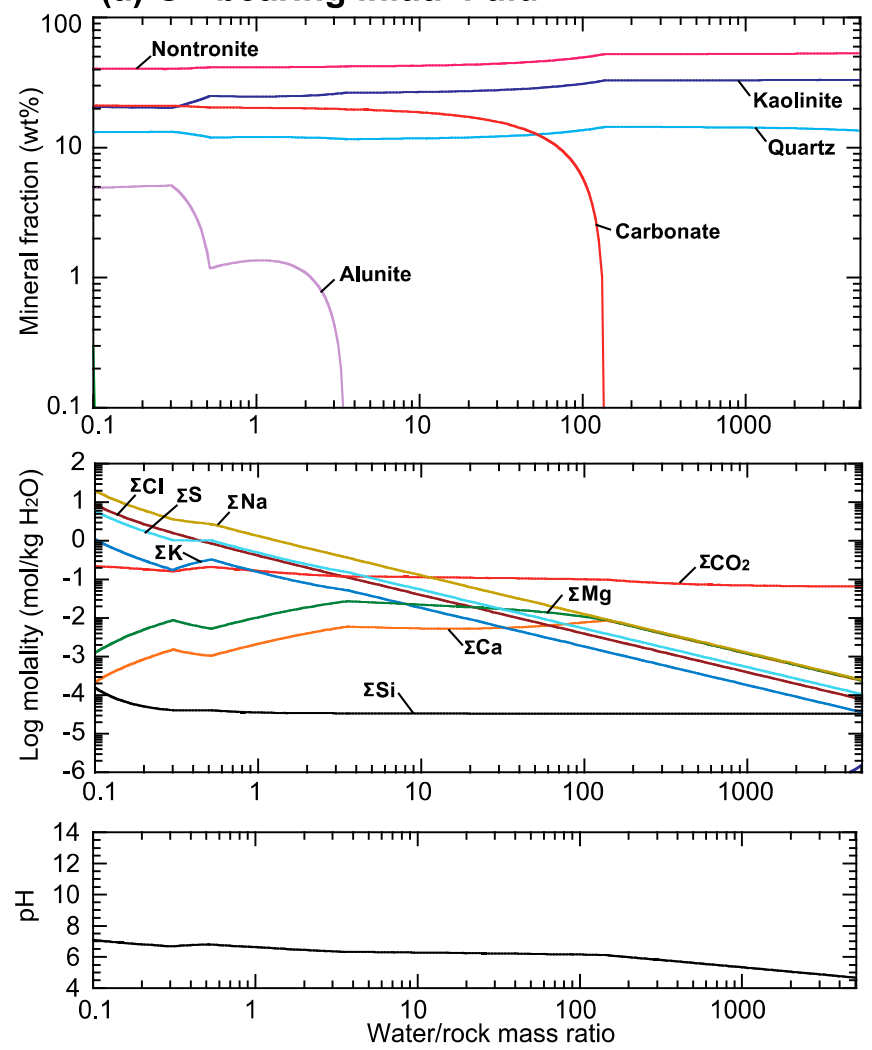

(b) $\mathrm{H}_{2}$-bearing initial fluid
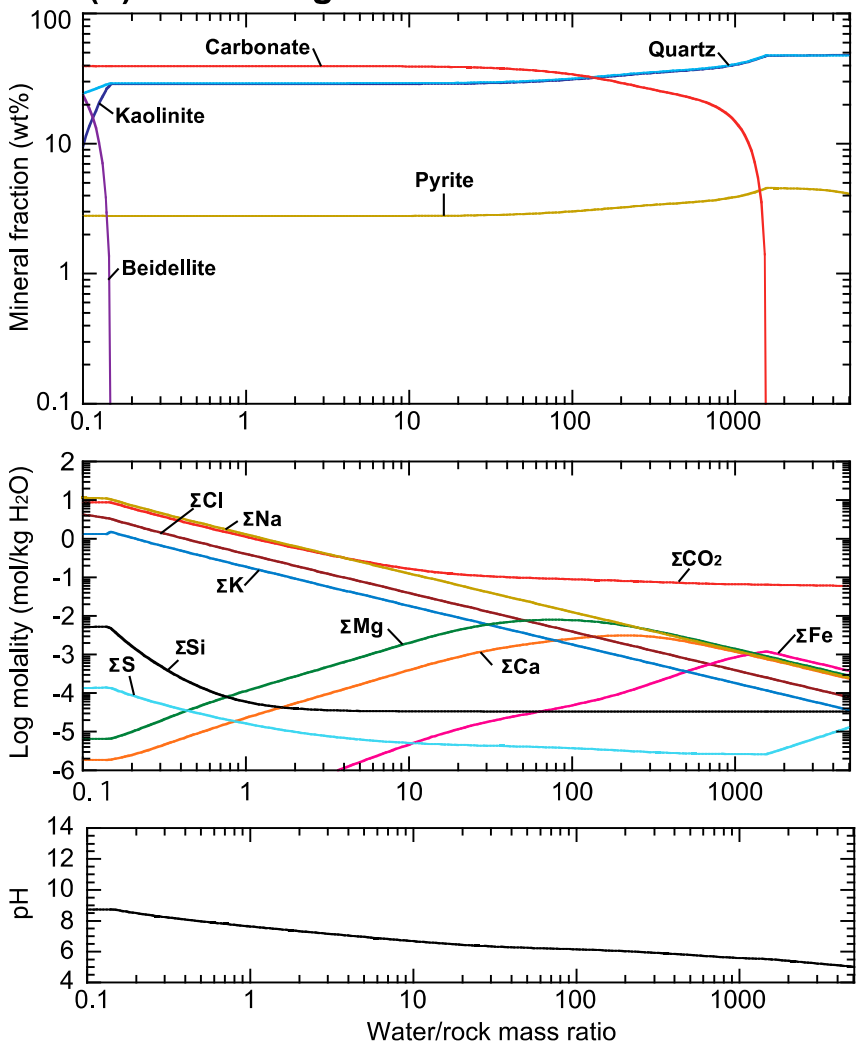

Figure 1. Results of the modeled secondary mineral assemblage and river water chemistry as a function of water-to-rock mass ratio $(\mathrm{W} / \mathrm{R})$ at $5{ }^{\circ} \mathrm{C}(\mathbf{a})$ initial fluid of I-R $\left(\mathrm{O}_{2}\right.$-bearing fluid); (b) initial fluid of II- $\mathrm{R}\left(\mathrm{H}_{2}\right.$-bearing fluid). Gas fugacities were fixed at values listed in Table 2 during the water-rock reactions.

The river water is rich in $\mathrm{Na}^{+}, \mathrm{Cl}^{-}$, and $\mathrm{SO}_{4}{ }^{2-}$ at low $\mathrm{W} / \mathrm{R}$ of $0.1-10$. In addition to these ions, $\mathrm{Mg}^{2+}, \mathrm{Ca}^{2+}$, and $\Sigma \mathrm{CO}_{2}$ are increasingly abundant at $\mathrm{W} / \mathrm{R}>10$. The $\mathrm{pH}$ of the river water is slightly acidic to neutral (4.7-7.1).

\subsubsection{Models with $\mathrm{H}_{2}$-Bearing Fluid (Case: II-R)}

The secondary minerals are dominated by carbonate, quartz, and kaolinite over a wide range of $W / R$. An equal amount of siderite, magnesite, and calcite comprise the carbonate solid solution at $\mathrm{W} / \mathrm{R}=0.1$, and the siderite fraction becomes the dominant carbonate species with increasing $\mathrm{W} / \mathrm{R}$.

The river water is rich in $\mathrm{Na}^{+}, \mathrm{Cl}^{-}$, and $\Sigma \mathrm{CO}_{2}$ throughout the modeled W/R. In addition to these ions, $\mathrm{Mg}^{2+}, \mathrm{Ca}^{2+}$, and $\mathrm{Fe}^{2+}$ become dominant ions at $\mathrm{W} / \mathrm{R}>100$. The $\mathrm{pH}$ of the river water is slightly acidic to alkaline (5.0-8.7). 


\subsection{Groundwater Chemistry and Secondary Mineral Assemblage}

\subsubsection{Models with $\mathrm{O}_{2}$-Bearing Initial Fluid (Case I-SG: Shallow Groundwater)}

In the case of subsurface water-rock reactions, there is a strong variability in the secondary mineral assemblages as a function of $\mathrm{W} / \mathrm{R}$, especially at low temperatures (5 and $25^{\circ} \mathrm{C}$ ). This fact is in contrast to the surface water-rock reactions that showed little variability in mineral assemblages throughout the modeled $\mathrm{W} / \mathrm{R}$.

At $5{ }^{\circ} \mathrm{C}$, secondary mineral assemblages are divided into three types on the basis of $\mathrm{W} / \mathrm{R}$ : low, intermediate, and high. At low W/R (0.1-10), secondary mineral assemblages are characterized by the dominance of saponite and beidellite, with minor abundances $(<10 \mathrm{wt} \%)$ of serpentine, anhydrite, portlandite, and carbonate (Figure $2 \mathrm{a})$.

$\mathrm{The} \mathrm{Fe} /(\mathrm{Mg}+\mathrm{Fe})$ ratio of saponite ranges from 0.72 to 0.86 (Figure A1 in Appendix A), suggesting the formation of Fe-rich saponite. Serpentine and carbonate solid solutions are dominantly present as chrysotile and calcite, respectively. The groundwater at this $\mathrm{W} / \mathrm{R}$ is enriched in $\mathrm{Cl}^{-}, \mathrm{Na}^{+}, \mathrm{NaHSiO}_{3}(\mathrm{aq})$, and $\mathrm{Ca}^{2+}$, and the $\mathrm{pH}$ is alkaline ( 12.2 to 13.1).

At intermediate $\mathrm{W} / \mathrm{R}(10-100), 5^{\circ} \mathrm{C}$, secondary mineral assemblages are characterized by the dominance of nontronite, kaolinite, carbonate, and quartz with minor abundances of serpentine (Figure 2a). At this W/R, two characteristic features can be found. One is that $\mathrm{Fe}^{3+}$ phase of smectite (i.e., nontronite) is the most dominant clay in the system, which is in contrast to the dominance of $\mathrm{Fe}^{2+}$ phase of smectite (Fe-rich saponite) at low W/R. The formation of nontronite is correlated with the generation of $\mathrm{H}_{2}$ (data not shown), suggesting that $\mathrm{H}_{2} \mathrm{O}$ reduction coupled to $\mathrm{Fe}^{2+}$ oxidation occurs at this W/R (10-100). Previous thermodynamic and experimental studies suggest that $\mathrm{pH}$ is the key parameter controlling the fraction of dioctahedral and trioctahedral phyllosilicate; dioctahedral clay is formed at more acidic conditions whereas trioctahedral clay is formed at more alkaline conditions [47]. This feature also explains change in dominant smectite with $\mathrm{W} / \mathrm{R}$ (Figure 2a); saponite and nontronite are the dominant smectite at low and intermediate $W / R$, respectively, because $\mathrm{pH}$ is more acidic at intermediate $\mathrm{W} / \mathrm{R}$ compared to that at low $\mathrm{W} / \mathrm{R}$. The other characteristic feature is the significant change in carbonate solid-solution compositions within a narrow $\mathrm{W} / \mathrm{R}$ range. The dominant carbonate solid solution is calcite at $\mathrm{W} / \mathrm{R}$ of $10-50$, but the dominant form is magnesite at $\mathrm{W} / \mathrm{R}$ of $50-75$, and then siderite becomes the dominant form at $W / R>75$. Those significant changes in solid-solution composition are reflected in the changes of $\mathrm{Mg}^{2+}$ and $\mathrm{Fe}^{2+}$ concentrations in groundwater; the concentration of $\mathrm{Mg}^{2+}$ and $\mathrm{Fe}^{2+}$ showed significant increases when magnesite and siderite start to form. The groundwater at intermediate $\mathrm{W} / \mathrm{R}$ is neutral to alkaline $\mathrm{pH}(7-12)$ and enriched in $\mathrm{Na}^{+}, \Sigma \mathrm{CO}_{2}$, and $\mathrm{Cl}^{-}$.

At high W/R (100-2000), $5{ }^{\circ} \mathrm{C}$, secondary mineral assemblages are characterized by the dominance of quartz, kaolinite, and carbonate (Figure 2a). The characteristic feature of this $\mathrm{W} / \mathrm{R}$ is that the groundwater is highly enriched in $\Sigma \mathrm{CO}_{2}, \mathrm{Fe}^{2+}, \mathrm{Mg}^{2+}$, and $\mathrm{Ca}^{2+}$. The $\mathrm{pH}$ is slightly acidic to neutral (5.4-6.6).

When temperatures increase to $25^{\circ} \mathrm{C}, 100{ }^{\circ} \mathrm{C}, 200^{\circ} \mathrm{C}$, the secondary mineral assemblages and groundwater chemistries showed several differences compared to those at $5{ }^{\circ} \mathrm{C}$. In the mineral phase, one of the significant changes observed is that the $W / R$ range where saponite + beidellite are dominantly formed extends to further higher $\mathrm{W} / \mathrm{R}$ with increasing temperature (Figure 2a-d). For example, the formations of saponite and beidellite are dominated at $\mathrm{W} / \mathrm{R}$ of $0.1-40$ at $25^{\circ} \mathrm{C}$ (Figure $2 \mathrm{~b}$ ), but their formations extend to $\mathrm{W} / \mathrm{R}$ of $0.1-100$ at $100{ }^{\circ} \mathrm{C}$ (Figure 2c). Furthermore, the $\mathrm{W} / \mathrm{R}$ at which nontronite is the dominant secondary phase extends to higher and wider ranges at $25^{\circ} \mathrm{C}$ and $100{ }^{\circ} \mathrm{C}$, compared to those for its formation temperature of $5{ }^{\circ} \mathrm{C}$. The other difference is that hematite and diaspore, which are not expected at $5{ }^{\circ} \mathrm{C}, 25^{\circ} \mathrm{C}$, and $100{ }^{\circ} \mathrm{C}$, are formed as minor phases at $200{ }^{\circ} \mathrm{C}$ and at high $\mathrm{W} / \mathrm{R}(>1000)$ (Figure $\left.2 \mathrm{~d}\right)$. Therefore, hematite and diaspore formations occur only at high temperatures. In the groundwater phase, the concentration of dissolved ion decreased with increasing temperature. Especially, the decrease in $\mathrm{Mg}^{2+}, \mathrm{Fe}^{2+}, \mathrm{Ca}^{2+}$, and $\Sigma \mathrm{CO}_{2}$ with increasing temperature is remarkable at high $\mathrm{W} / \mathrm{R}$ ranges. 
(a) $5^{\circ} \mathrm{C}$
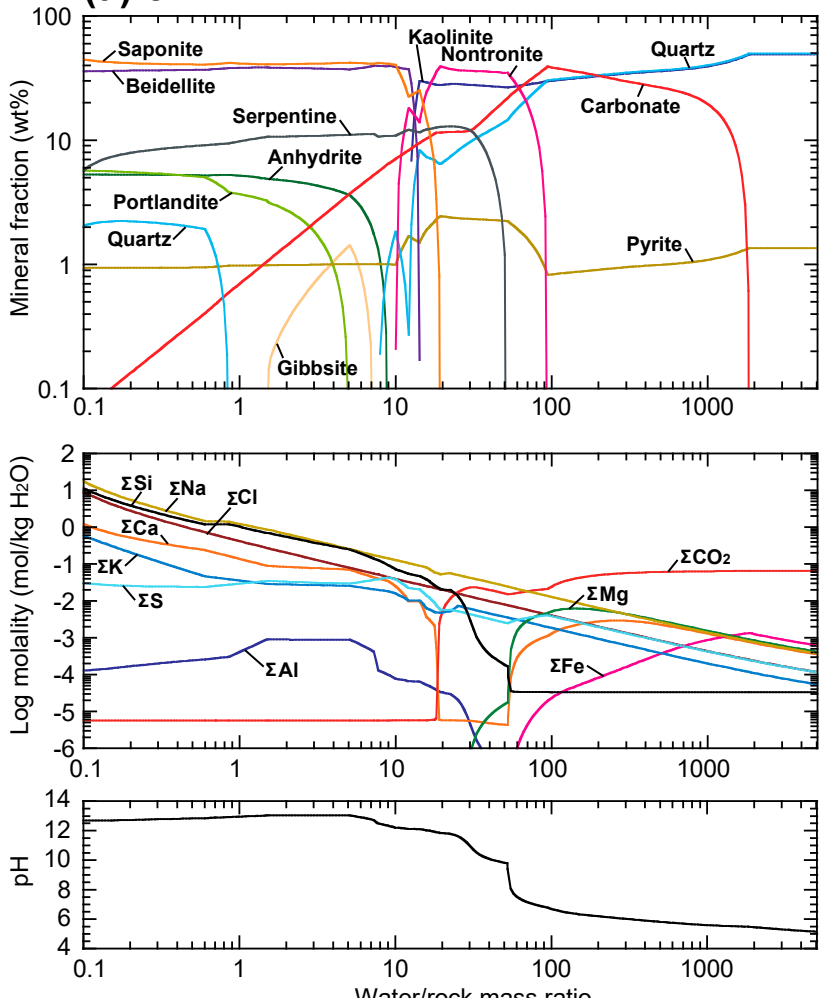

(c) $100^{\circ} \mathrm{C}$
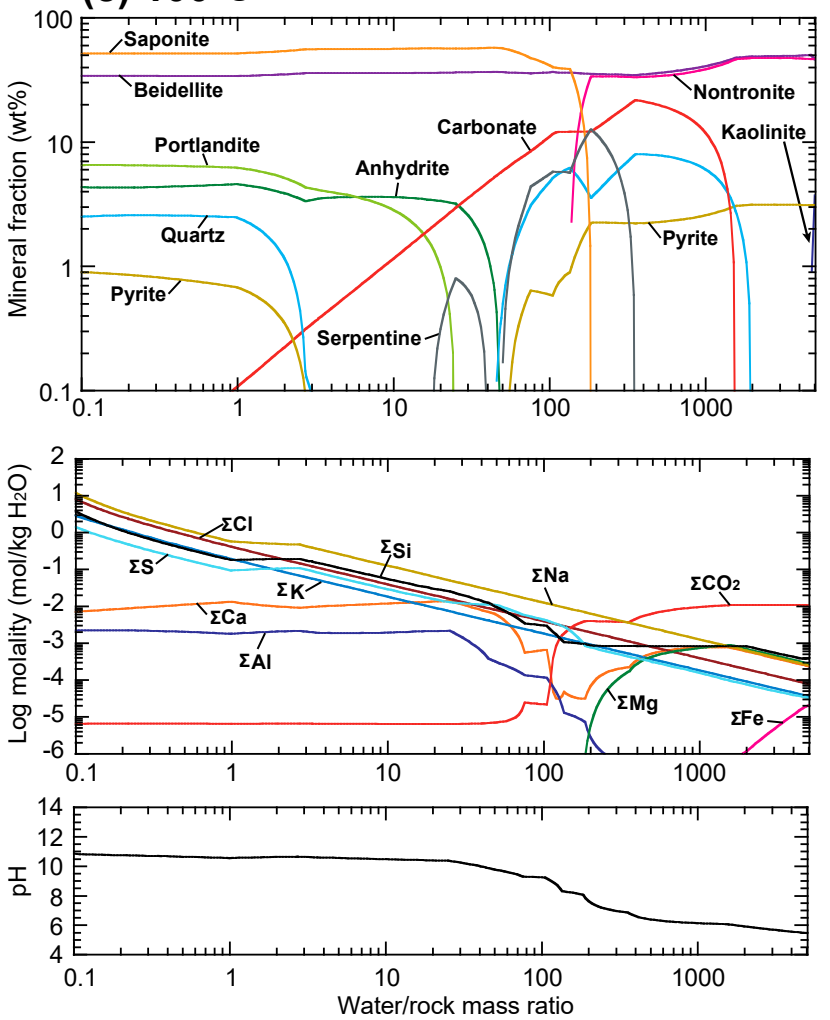

(b) $25^{\circ} \mathrm{C}$
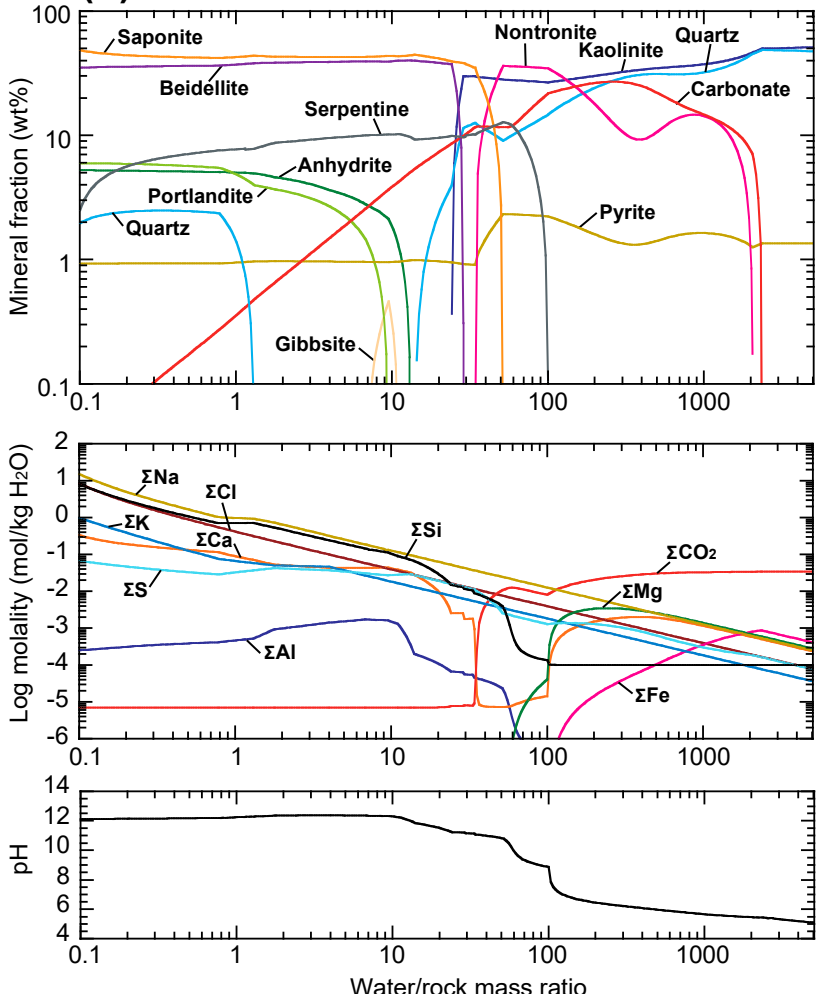

(d) $200^{\circ} \mathrm{C}$
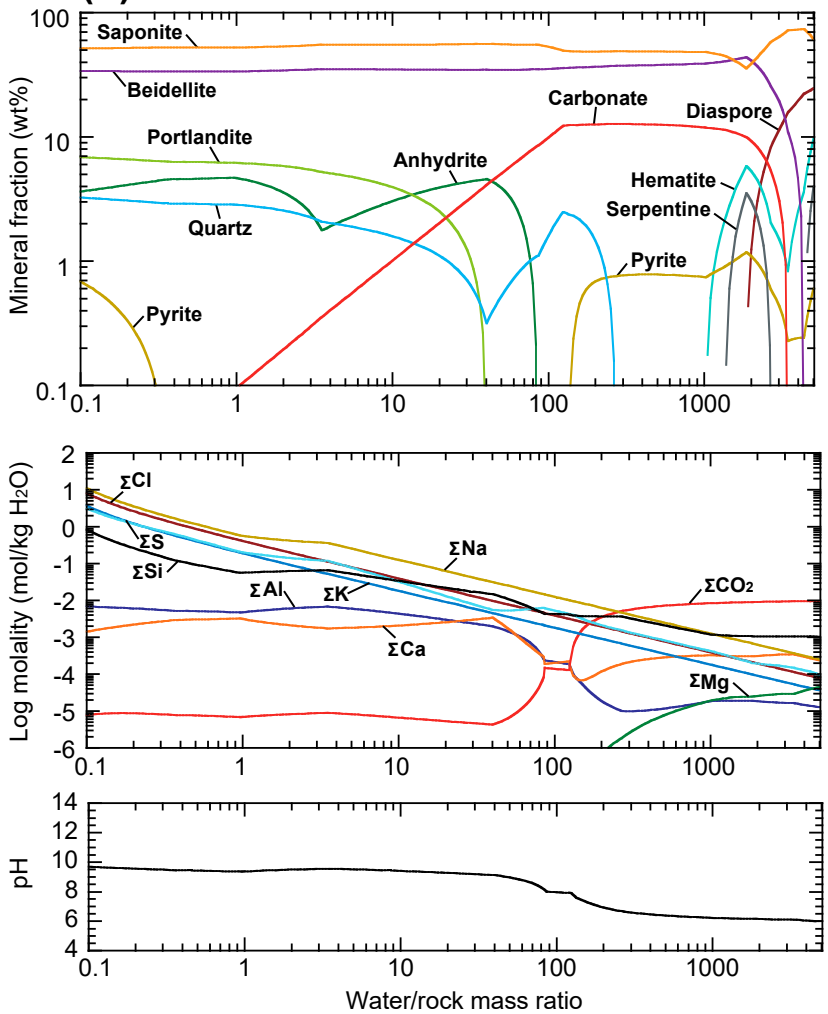

Figure 2. Secondary mineral assemblage, ion concentrations in groundwater, and $\mathrm{pH}$ as a function of water-to-mass ratio $(\mathrm{W} / \mathrm{R})$ when rock reacted with $\mathrm{O}_{2}$-bearing initial fluid (Case I-SG) at temperatures of (a) $5{ }^{\circ} \mathrm{C}$; (b) $25^{\circ} \mathrm{C}$; (c) $100{ }^{\circ} \mathrm{C}$; and (d) $200{ }^{\circ} \mathrm{C}$. Gas fugacities were not fixed during water-rock reactions. 


\subsubsection{Models with $\mathrm{H}_{2}$-Bearing Initial Fluid (Case II-SG: Shallow Groundwater)}

The secondary mineral assemblages and groundwater compositions when rock reacted with $\mathrm{H}_{2}$-bearing initial fluid are almost the same as those suggested from $\mathrm{O}_{2}$-bearing fluids at 5-200 ${ }^{\circ} \mathrm{C}$ (Figures $2 \mathrm{a}-\mathrm{d}$ and $3 \mathrm{a}-\mathrm{d}$ ). In particular, mineral assemblage at $\mathrm{W} / \mathrm{R}$ of $0.1-100$ is completely the same as those suggested from $\mathrm{O}_{2}$-bearing initial fluid. Slight differences observed are limited to high $\mathrm{W} / \mathrm{R}$, for example, a higher amount of nontronite formed at $25{ }^{\circ} \mathrm{C}$ when rock reacted with $\mathrm{H}_{2}$-bearing fluid. These results suggest that the $p \mathrm{CO}_{2}$, rather than $p \mathrm{O}_{2}$ and $p \mathrm{H}_{2}$ in the initial fluid, plays an important role in controlling the secondary mineral assemblage and groundwater composition, at least within our modeled $p \mathrm{H}_{2}$ and $p \mathrm{O}_{2}$.

(a) $5^{\circ} \mathrm{C}$

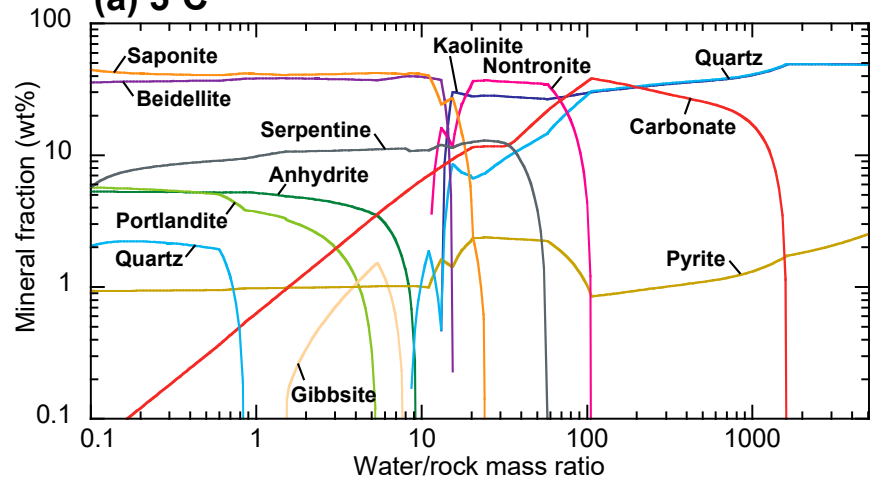

(c) $100^{\circ} \mathrm{C}$

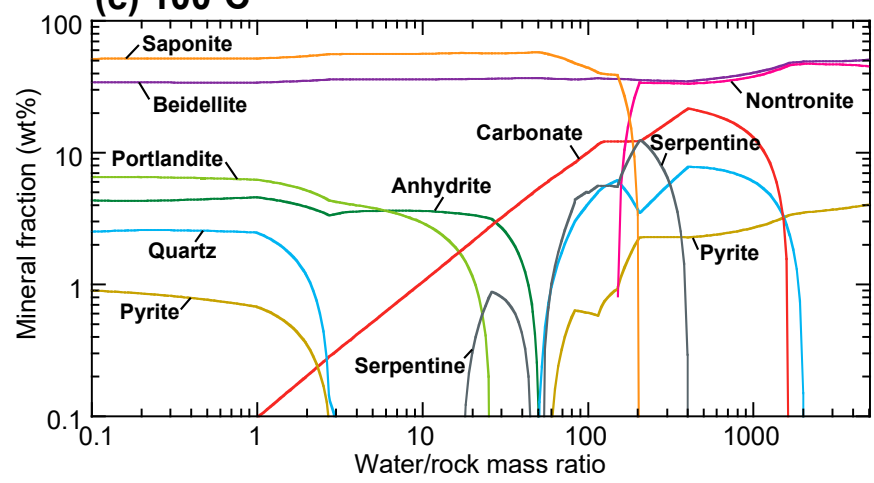

(b) $25^{\circ} \mathrm{C}$

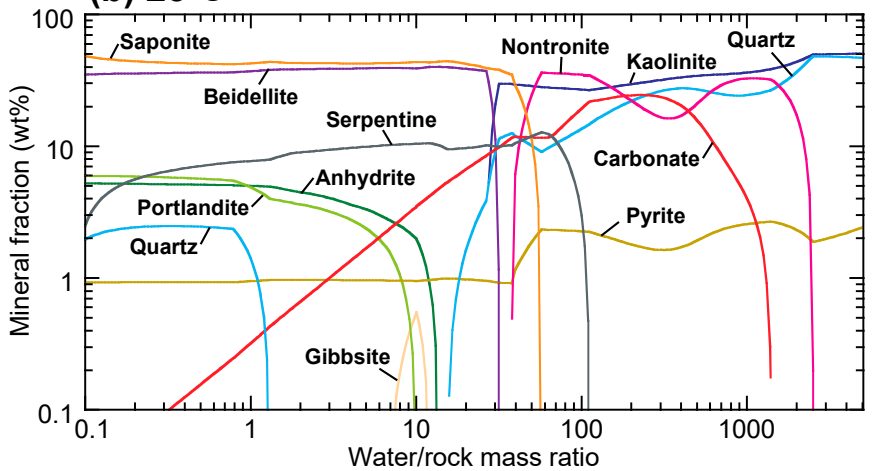

(d) $200^{\circ} \mathrm{C}$

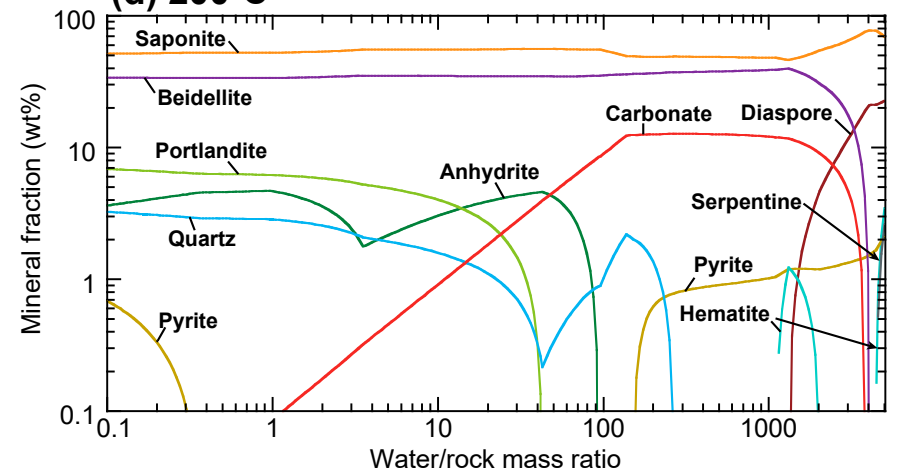

Figure 3. Secondary mineral assemblages when rock reacted with $\mathrm{H}_{2}$-bearing initial fluid (Case II-SG) at temperatures of (a) $5{ }^{\circ} \mathrm{C}$; (b) $25^{\circ} \mathrm{C}$; (c) $100{ }^{\circ} \mathrm{C}$; and (d) $200{ }^{\circ} \mathrm{C}$. Gas fugacities were not fixed during the water-rock reactions. The results are almost completely the same as those obtained from $\mathrm{O}_{2}$-bearing initial fluid.

\subsubsection{Models with Gas-Free Initial Fluid (Case III-DG: Deep Groundwater)}

In deep subsurface layers where gas-free initial fluid reacts with rock at $5{ }^{\circ} \mathrm{C}$, the secondary phase is dominated by Fe-rich saponite throughout the modeled W/R (Figure 4a). In addition, beidellite or kaolinite is suggested as the second most abundant phase at $\mathrm{W} / \mathrm{R}$ of $0.1-50$ and $50-5000$, respectively. Serpentine is present as a minor phase and mainly comprises chrysotile. Groundwater is alkaline $(\mathrm{pH} 11-13)$ and enriched in $\mathrm{Na}^{+}$, $\mathrm{NaHSiO}_{3}(\mathrm{aq}), \mathrm{Cl}^{-}$, and $\mathrm{Ca}^{2+}$. 
(a) $5^{\circ} \mathrm{C}$
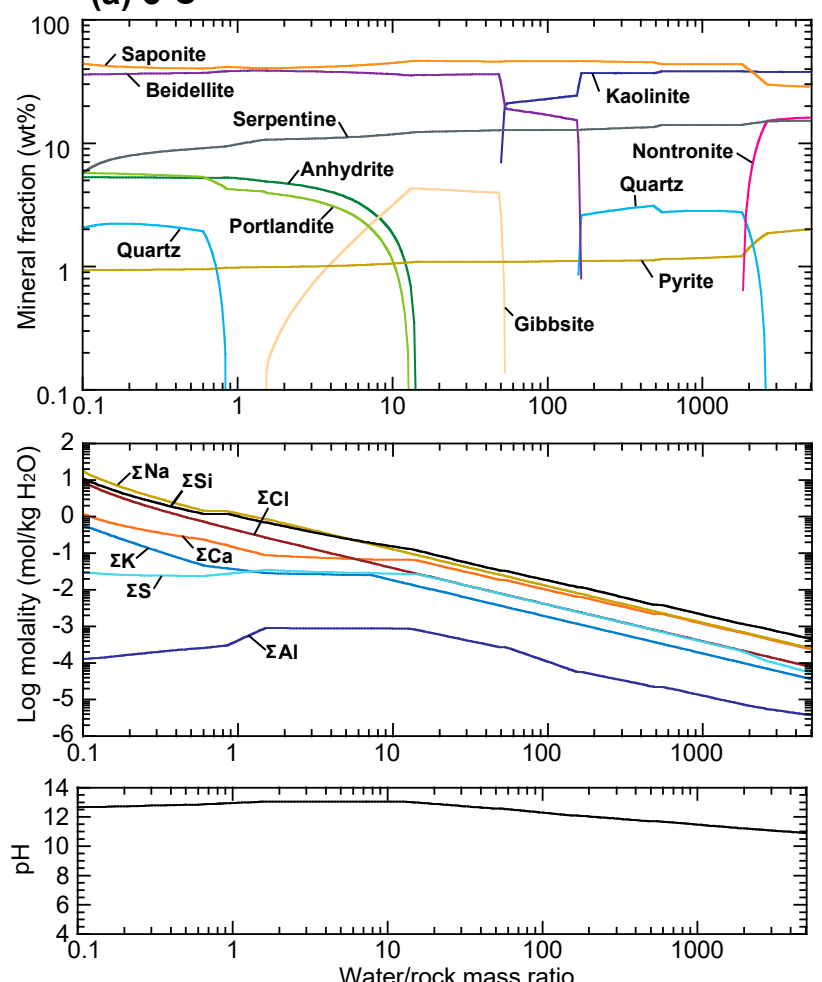

(c) $100^{\circ} \mathrm{C}$
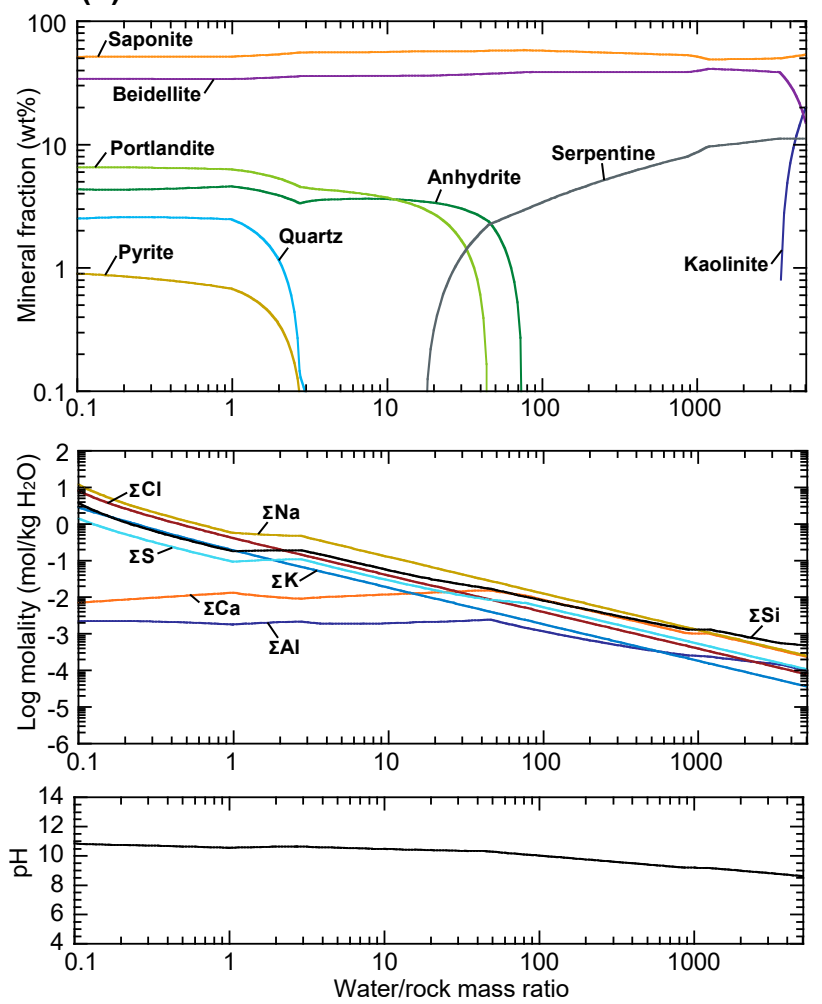

(b) $25^{\circ} \mathrm{C}$
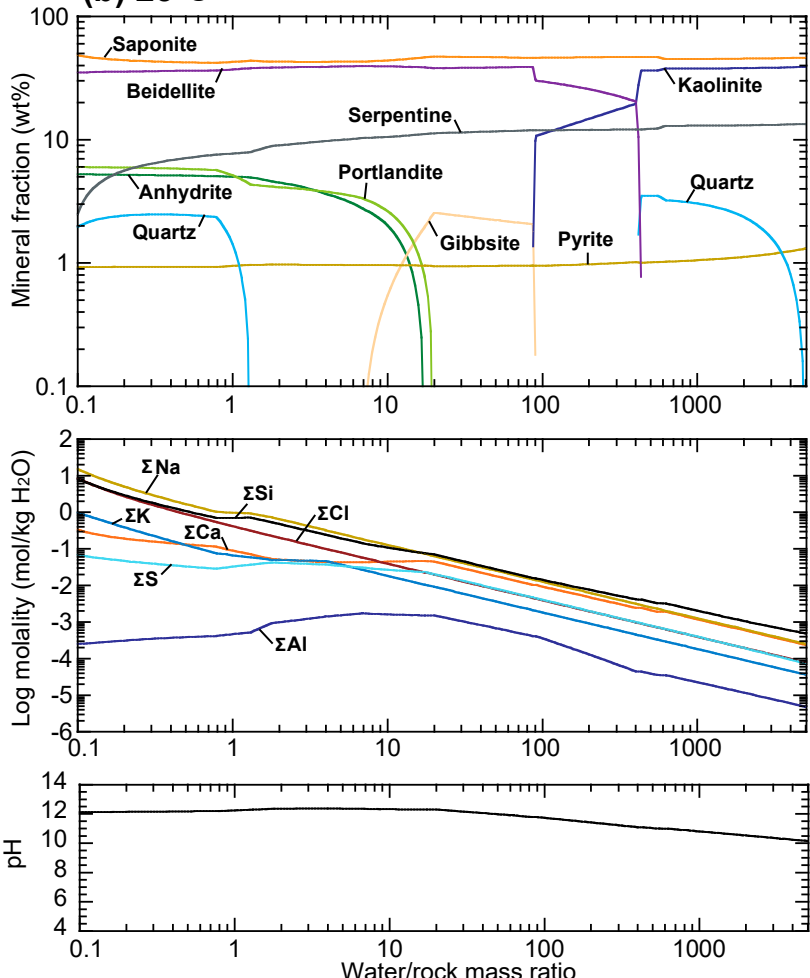

(d) $200^{\circ} \mathrm{C}$
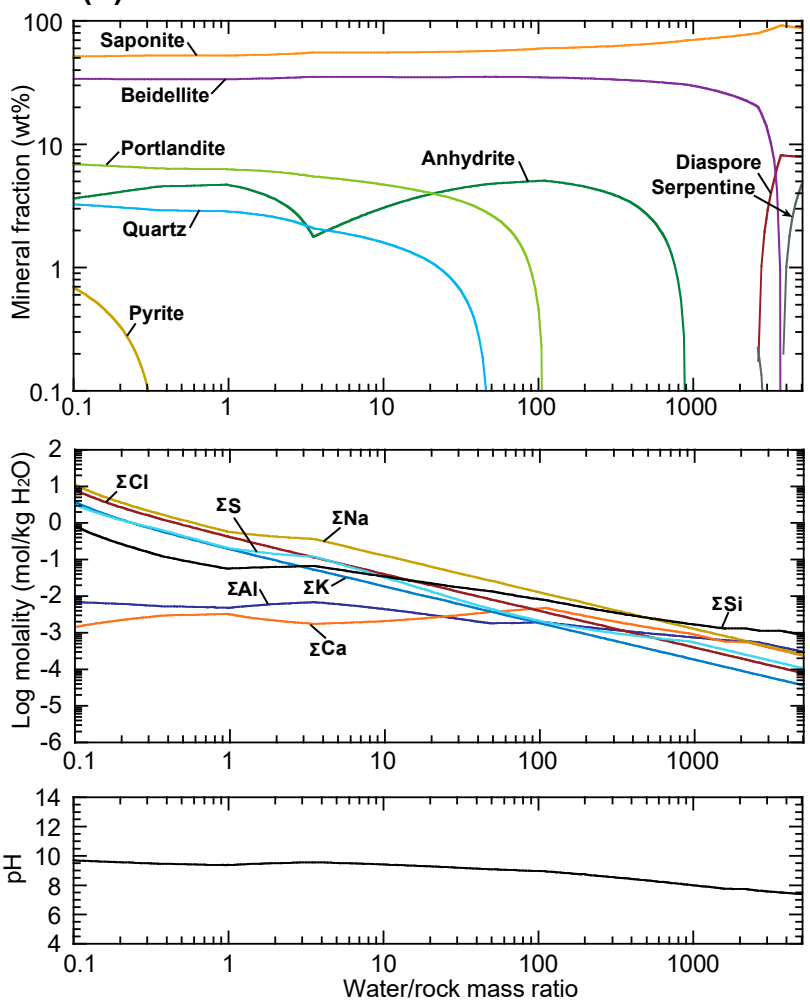

Figure 4. Results of the modeled secondary mineral assemblage, dissolved ion concentration in groundwater, and $\mathrm{pH}$ when Mars rock reacted with gas-free initial fluid (Case III-DG) at (a) $5{ }^{\circ} \mathrm{C}$; (b) $25^{\circ} \mathrm{C}$; (c) $100{ }^{\circ} \mathrm{C}$; and (d) $200{ }^{\circ} \mathrm{C}$.

When the temperatures increase to $25^{\circ} \mathrm{C}, 100{ }^{\circ} \mathrm{C}$, and $200{ }^{\circ} \mathrm{C}$, the overall results of a Fe-rich saponite-dominated assemblage do not change (Figure $4 \mathrm{~b}-\mathrm{d}$ ). However, the amount of Fe-rich saponite increases with increasing temperature, which is probably due to 
the fact that the formation of less serpentine or the absence of serpentine (mainly chrysotile) at high temperature results in a higher distribution of $\mathrm{Mg}$ in saponite.

The secondary mineral assemblages and water chemistries suggested from the gas-free initial water did not show significant difference from those suggested from $\mathrm{O}_{2}-/ \mathrm{H}_{2}$-bearing fluid, at low $\mathrm{W} / \mathrm{R}(0.1-100)$. This is because the amount of carbonate, which usually formed in the case of the $\mathrm{O}_{2}-/ \mathrm{H}_{2}$-bearing fluid, is not abundant at low $\mathrm{W} / \mathrm{R}$, and the absence of carbonate from the gas-free initial fluid does not result in a significant difference in the secondary mineral assemblage and groundwater chemistry. At intermediate to high $\mathrm{W} / \mathrm{R}$, in contrast, the secondary mineral assemblage suggested from the gas-free initial fluid is quite different from that suggested from the $\mathrm{O}_{2}-/ \mathrm{H}_{2}$-bearing initial fluid. This is because carbonate is the dominant secondary phase in the $\mathrm{O}_{2}-/ \mathrm{H}_{2}$-bearing initial fluid, and the absence of this phase significantly changes both the mineral and water conditions. The dominance of Fe-rich saponite and absence of carbonate from the gas-free initial fluid results in a negligible amount of $\mathrm{Fe}^{2+}, \mathrm{Ca}^{2+}$, and $\mathrm{Mg}^{2+}$ in the groundwater, which is in contrast to the dominance of these ions suggested from the $\mathrm{O}_{2}-/ \mathrm{H}_{2}$-bearing initial fluid; also, $\mathrm{pH}$ is more alkaline in the case of gas-free water than that suggested from the $\mathrm{O}_{2}-/ \mathrm{H}_{2}$-bearing initial fluid.

\subsection{Potential Physicochemical Condition for Saponite Formation in Gale Crater}

Smectite is one of the most abundant clay minerals detected in Sheepbed mudstone of Yellowknife Bay [5], which is likely formed due to low-temperature chemical weathering of rocks [23]. The detailed X-ray diffraction analyses suggest that ferrian $\left(\mathrm{Fe}^{3+}\right)$ saponite is the main phase of smectite $[24,48]$. However, it may also be that ferrian saponite is originally present as ferrous saponite but is oxidized over time [17,49].

If ferrous saponite is the main smectite phase when Sheepbed mudstone was formed, the formation of this phase was explained by a wide range of $W / R$, temperatures, and initial rock compositions such as olivine, glass, Martian meteorite (ALH84001), and basaltic rock (Mazatzal basalt) [50-52]. In addition to these studies, our study, using igneous composition as an initial rock, revealed the formation of Fe-rich saponite by subsurface water-rock reactions (Figures 2-4). In contrast, the formation of saponite is not suggested for the surface water-rock reactions, irrespective of the gas species in the initial fluids (Figure 1). These results suggest that the water-rock reactions at "subsurface" where gas exchange is limited is important to explain saponite formation in Sheepbed mudstone of Yellowknife Bay.

In the subsurface water-rock reactions, however, Fe-rich saponite formation can occur under various conditions of $\mathrm{W} / \mathrm{R}(0.1-5000)$, temperatures $\left(5^{\circ} \mathrm{C}-200^{\circ} \mathrm{C}\right)$, and initial fluid compositions $\left(\mathrm{O}_{2}\right.$-bearing, $\mathrm{H}_{2}$-bearing, and gas-free fluids) in our calculations (Figures 2-4). In addition, Fe-rich saponite is the most dominant secondary mineral phase, as is consistent with the previous thermodynamic calculations [50]. Such an abundant formation of Fe-rich saponite well account for the dominant presence of saponite in Sheepbed mudstone of Yellowknife Bay. If we consider low-temperature water-rock reactions at ca. $5{ }^{\circ} \mathrm{C}$, the formation of Fe-rich saponite is explained at a W/R of 0.1-10 (Figure 2a). Furthermore, considering that carbonate fraction in Gale crater is less than $1 \mathrm{wt} \%$ [53], the water-rock reactions at $\mathrm{W} / \mathrm{R}$ less than 1.4 can explain the scarcity of carbonate. Such $\mathrm{W} / \mathrm{R}$ can be achieved under various subsurface conditions in natural systems. It is therefore possible that Fe-rich saponite is formed through subsurface water-rock reactions near the rim of Gale crater and supplied to mudstone during erosion in Gale (Figure 5) [52]. However, it is also possible that the formation of Fe-rich saponite has an autochthonous origin (e.g., diagenesis) $[5,35]$. 


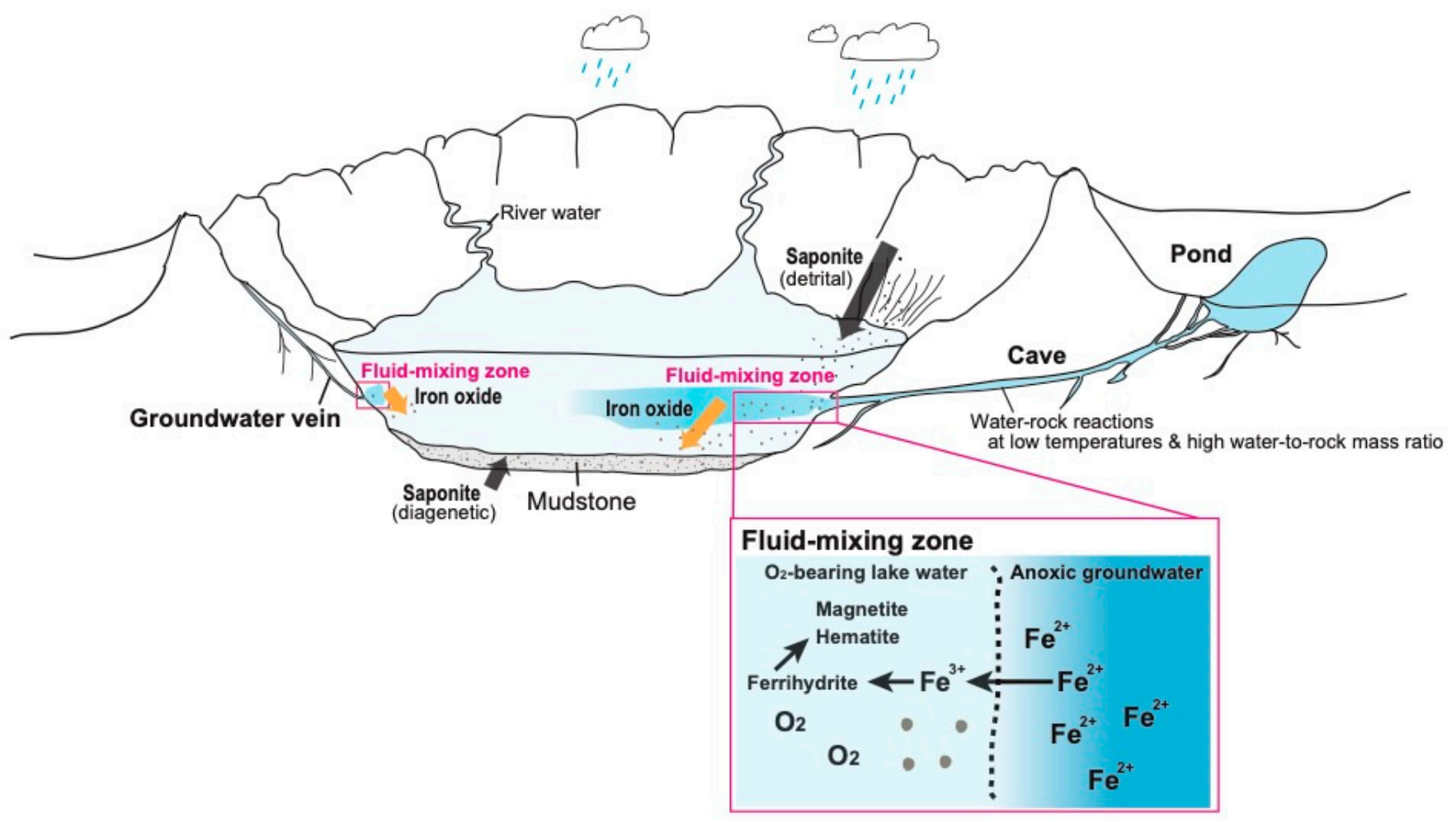

Figure 5. Schematic of possible formation scenario of saponite and iron oxides (magnetite and hematite) in Gale crater.

\subsection{Potential Physicochemical Condition for Hematite and Magnetite Formation}

In addition to saponite, iron oxides such as magnetite and hematite detected in Sheepbed mudstone are considered as authigenic origin $[3,23]$. The low values of chemical index of alteration (CIA) in this mudstone suggests that iron oxides formed by diagenesis under the conditions of low-temperature, circumneutral, and low W/R [23]. Indeed, previous thermodynamic calculations showed the formation of magnetite and hematite even at low temperatures (e.g., $10^{\circ} \mathrm{C}$ ) and the fraction of magnetite formed increases with increasing temperatures [50]. In contrast to the previous studies, our thermodynamic modeling cannot explain the formation of magnetite at low W/R and temperature $>200^{\circ} \mathrm{C}$. A significant difference between our and the previous thermodynamic calculations is the $\mathrm{Fe}^{2+} / \mathrm{Fe}^{3+}$ ratios in the initial solid phases; the sole presence of $\mathrm{FeO}$ is assumed in this study, whereas both $\mathrm{FeO}+\mathrm{Fe}_{2} \mathrm{O}_{3}$ are considered in the previous studies [50,52]. Therefore, it should be first noted that the formation condition of iron oxides depends on the initial $\mathrm{Fe}^{2+} / \mathrm{Fe}^{3+}$ condition. However, our thermodynamic calculations revealed that the iron oxides can be formed even if $\mathrm{Fe}$ (III) is not included in the original rock.

Our thermodynamic calculations with various conditions of temperature and initial fluid compositions numerically provide two possible conditions for iron oxide formation. The first one is the water-rock reactions at high temperature $\left(>200^{\circ} \mathrm{C}\right)$ and high $\mathrm{W} / \mathrm{R}$ (>1000), which causes a coincidence with Fe-rich saponite (Figure 2d). However, the absence of chlorite and illite in Sheepbed mudstone, which usually require alteration temperatures of $\sim 60^{\circ} \mathrm{C}$ to $80^{\circ} \mathrm{C}$, suggests that the mudstone did not experience high-temperature waterrock reactions [5]. Moreover, given the geothermal gradient of approximately $20 \mathrm{~K} / \mathrm{km}$ on early Mars [54], the water-rock reactions at $200{ }^{\circ} \mathrm{C}$ corresponds to a depth of $10 \mathrm{~km}$ below the surface (assuming a surface temperature of $0{ }^{\circ} \mathrm{C}$ ). Achieving water-rock reactions at high $W / R(>1000)$ at this depth would be geologically unrealistic.

The other possibility is the formation of iron oxides in the fluid-mixing zone where the $\mathrm{O}_{2}$-bearing surface water encountered $\mathrm{Fe}^{2+}$-rich groundwater. The formation of iron oxides (e.g., ferrihydrite, goethite, and magnetite) in such a fluid-mixing zone is quite common in terrestrial settings, including seafloor hydrothermal vents and groundwater discharge 
zones [55]. The possible existence of fluid-mixing zone is indeed suggested in Gale lake, though at a different stratum (Murray formation) [4]. Based on our results, however, one of the most characteristic features of this scenario is that water-rock reactions at lower temperatures and high $\mathrm{W} / \mathrm{R}$ are more preferable for generating a high concentration of $\mathrm{Fe}^{2+}$ in groundwater (Figure 2a-d): the greater the decrease in the reaction temperature, the higher is the $\mathrm{Fe}^{2+}$ concentration in groundwater. In addition, high $\mathrm{Fe}^{2+}$ concentration in groundwater is suggested only when the rock reacted with $\mathrm{CO}_{2}$-bearing fluids (Figure 2); the dissolved $\mathrm{Fe}^{2+}$ is negligible throughout the examined temperature and $\mathrm{W} / \mathrm{R}$ when rock reacted with gas-free fluid (Figure 4). These results, combined with the proposed cold environment [23] and a dense $\mathrm{CO}_{2}$ atmosphere [30], indicate that early Mars would have been favorable for generating high $\mathrm{Fe}^{2+}$-containing groundwater, and thus, it had the potential to precipitate iron oxides in the fluid-mixing zone.

To further examine the possibility of iron oxides formation in the fluid-mixing zone, we discuss the potential mineral precipitation based on two thermodynamic constraints on minerals; the saturation indices (SI) in the mixing zone when mineral precipitation is suppressed and the secondary mineral assemblages when mineral-fluid equilibrium is achieved. The fluid compositions of the two fluids used for the calculations are listed in Table 3. In the modeling, we assumed that ancient lakes in Gale crater were sustained dominantly by rivers [56], and thus we simply used the composition of river water generated by reactions between rock and the $\mathrm{O}_{2}$-bearing initial fluid. The $\mathrm{W} / \mathrm{R}$ of river water is unknown but temporarily fixed as 3000 because the water-rock reactions between flowing river water and the river basement generally proceed at high $W / R$. The groundwater composition is taken from the modeling results of reactions between rock and the $\mathrm{O}_{2}$-bearing initial fluid at $\mathrm{W} / \mathrm{R}$ of 1000 and $5{ }^{\circ} \mathrm{C}$.

Table 3. Calculated chemical composition of groundwater and river water that assumed to have been present in Gale. The values are calculated by thermodynamic calculations simulating water-rock reactions.

\begin{tabular}{ccc}
\hline & Groundwater & River Water \\
\hline Initial fluid & $\mathrm{I}-\mathrm{SG}$ & $\mathrm{I}-\mathrm{R}$ \\
$\mathrm{W} / \mathrm{R}$ & 1000 & 3000 \\
$\mathrm{~T}\left({ }^{\circ} \mathrm{C}\right)$ & 5 & 5 \\
$\mathrm{pH}$ & 5.6 & 4.9 \\
$\mathrm{Na}$ & 1.4 & 0.42 \\
$\mathrm{~K}$ & 0.20 & 0.061 \\
$\mathrm{Ca}$ & 1.3 & 0.40 \\
$\mathrm{Mg}$ & 1.5 & 0.41 \\
$\mathrm{Fe}$ & 0.87 & $1.4 \times 10^{-8}$ \\
$\mathrm{~S}$ & 0.42 & 0.18 \\
$\mathrm{Cl}$ & 0.43 & 0.13 \\
$\Sigma \mathrm{CO}_{2}$ & 64 & 67 \\
$\mathrm{SiO}_{2}$ & 0.033 & 0.033 \\
\hline
\end{tabular}

Concentrations in mmolal.

The results of calculated SI as a function of lake water-to-groundwater ratio are shown in Figure 6a. The SI values of nontronite, iron oxides, kaolinite, gibbsite, and quartz were higher than 1 under a wide range of lake water-to-groundwater ratios, suggesting that the mixed fluid is saturated in these minerals. Especially, nontronite and iron oxides are highly saturated in the following order, when the lake water-to-groundwater ratio is 1 : $(\mathrm{Fe}-, \mathrm{Mg}-, \mathrm{Ca}-)$ nontronite $>$ hematite $>\mathrm{K}$-nontronite $>$ magnetite $>$ goethite $>$ bernalite. These results suggest that both magnetite and hematite are included in candidates for the minerals actually precipitated in the fluid-mixing zone. 
(a)

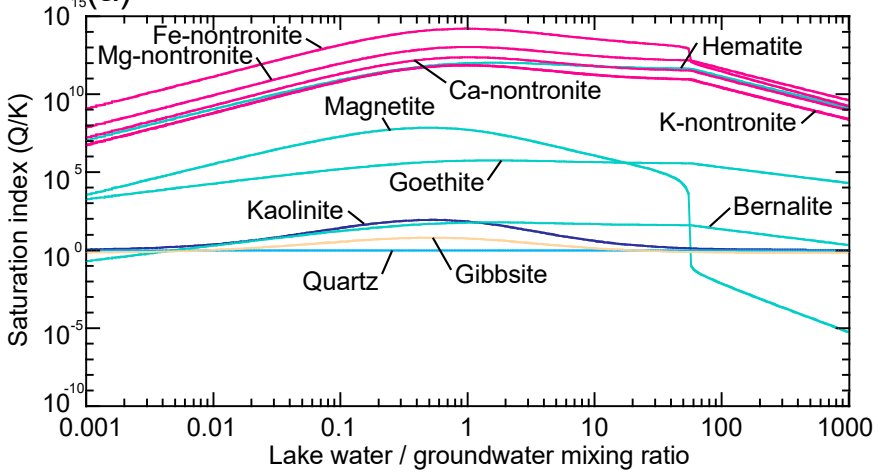

(b)

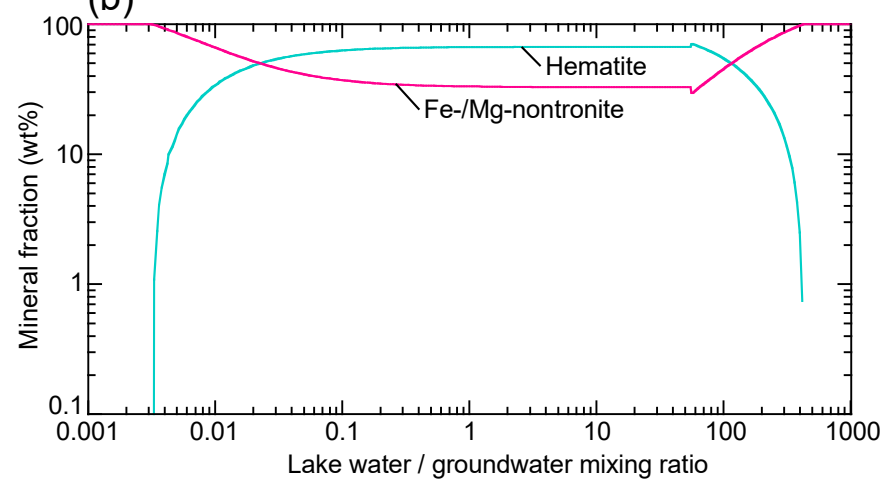

Figure 6. (a) mineral saturation indices and (b) mineral assemblages when lake water and groundwater (composition shown in Table 3) mixed under various lake water-to-groundwater mixing ratio at $5{ }^{\circ} \mathrm{C}$.

Furthermore, the kinetic effect is an important factor involved in the mineral precipitation, and therefore, the order of SI calculated do not necessarily match the exact phases observed in natural systems. For example, the fluid of the weathered volcanic ash deposits on Earth (Sakurajima volcanic, Japan) are saturated with cristobalite, amorphous $\mathrm{Al}(\mathrm{OH})_{3}$, and ferrihydrite, and significantly oversaturated with kaolinite, montmorillonite, and "nontronite"; however, only "ferrihydrite", cristobalite, and poorly ordered Al-Si-Fe minerals were detected in the deposit [57]. Therefore, it is highly possible that ferrihydrite precipitated first and then eventually transformed into hematite or magnesite on Mars. In addition, our additional thermodynamic calculations simulating an equilibrium fluid mixing (mineral precipitation allowed) indicate the dominant formation of hematite in a wide range of lake water-to-groundwater mixing ratio (Figure 6b) even though the SI of hematite is lower than those of nontronite in the earlier calculations (Figure 6a). This suggests that the fluid mixing zone had the sufficient capacity to form a large amount of iron oxide.

To understand the dependence of SI in fluid mixing zone on atmospheric $p \mathrm{O}_{2}$, we additionally calculated SI of minerals in fluid mixing zone using two more different $p \mathrm{O}_{2}$ : $20 \mathrm{mbar}$ and $0.01 \mathrm{mbar}$. The $0.01 \mathrm{mbar}$ of $p \mathrm{O}_{2}$ is within the range of tropospheric $p \mathrm{O}_{2}$ suggested from the photochemical model [58]. In contrast, 20 mbar of $p \mathrm{O}_{2}$ is not proposed previously; we temporarily used this value as the case that the early Mars could have highly oxidizing conditions. The $\mathrm{W} / \mathrm{R}$ of the water-rock reactions that generate lake water and groundwater are the same as those used for 2 mbar $\mathrm{pO}_{2}$ (3000 for lake water and 1000 for groundwater, respectively). The results suggest that $\mathrm{SI}$ values decrease with decreasing $p \mathrm{O}_{2}$ (Figures 6a and A2). However, SI values of hematite and goethite are higher than 1 in a wide range of lake water-to-groundwater mixing ratios even under the condition of $0.01 \mathrm{mbar} p \mathrm{O}_{2}$. These results suggest that the formation of iron oxides in fluid mixing zone can be explained not only by the $p \mathrm{O}_{2}$ inferred from the stability of $\mathrm{MnO}_{2}$ formation [32] but also those predicted by the photochemical reactions (of course also explained by highly $\mathrm{O}_{2}$-enriched atmosphere).

Therefore, the formation of hematite and magnetite observed in the Sheepbed mudstone can be explained also by the fluid-mixing between $\mathrm{O}_{2}$-bearing lake water and Fe-rich groundwater. However, we note that processes such as reaction with other oxidants (e.g., $\mathrm{H}_{2} \mathrm{O}_{2}$, chlorate, photooxidation, and sulfate) [59] and alteration of $\mathrm{Fe}(\mathrm{II}) / \mathrm{Fe}(\mathrm{III})$-bearing minerals could also contribute to the formation of iron oxides $[50,60]$. This study simply proposes a fluid mixing zone as an additional geological process for iron oxide formation, based on the thermodynamic calculations. Although the generation of the Fe-rich groundwater requires high $\mathrm{W} / \mathrm{R}(>1000)$ even underground, such high $\mathrm{W} / \mathrm{R}$ could be presumably achieved in the specific geological setting such as relatively large underground water veins and subterranean caves below/near Gale crater (Figure 5). On Earth, for example, it is well known that seafloor hydrothermal venting generates a huge hydrothermal 
plume (occasionally expanding to several thousands of kilometers away in horizontal distance) [61], indicating that fluid mixing is not exclusive to local process depending on inflow rate of groundwater. Therefore, it is possible that the chemical precipitation due to the fluid mixing was recorded as minerals (e.g., iron oxides) in sediments throughout the lake. In this case, the sediments in Yellowknife Bay would have occurred as a relatively homogeneous mixture of terrigenous minerals and chemical precipitates possibly with sedimentation textures, which is consistent with the occurrence of smectite (e.g., saponite) and iron oxides in Sheepbed mudstone.

If this is the case, such geological processes could occur even after the sedimentation of Sheepbed mudstone in Yellowknife Bay. Indeed, iron oxide (hematite and magnetite) possibly formed at the redox interface between anoxic and oxic waters are detected in other overlying iron-rich strata, such as Murray formation [4]. Therefore, the fluid-mixing model can be applicable not only to Sheepbed mudstone but also other strata bearing iron oxides.

\subsection{Available Free Energy in the Lake Water-Groundwater Mixing Zone}

The formation of magnetite and hematite in the fluid-mixing zone in Gale crater provides an important insight into the habitability of early Mars. That is, the $\mathrm{Fe}^{2+}$ present in the groundwater can be the potential energy source for life. In terrestrial fluid-mixing zones where $\mathrm{Fe}^{2+}$-rich anoxic groundwater mixes with the oxygenated surface water (via, for, e.g., hydrothermal vents and groundwater discharge areas), chemolithoautotrophic $\mathrm{Fe}^{2+}$-oxidizing microbes are one of the most common primary producers in the microbial ecosystem; they significantly contribute to the iron oxide precipitation, carbon fixation, and the ecosystem functioning $[62,63]$. In this study, we considered the energy availability through aerobic $\mathrm{Fe}^{2+}$ oxidation in the possible lake water-groundwater mixing zone in early Gale crater.

The fluid compositions used in the energy calculations are the same as those listed in Table 3. For the comparison of bioavailable energy in fluid-mixing zone between Mars and Earth, we also conducted free energy calculations for a pond-water-groundwater mixing zone on Earth (Budo-pond, Hiroshima, Japan), where the dominance of aerobic $\mathrm{Fe}^{2+}$-oxidizing microbes was confirmed by DNA analysis [64-67]. The free energy per kilogram of mixed fluid on Mars and Earth are shown in Figure 7a,b, respectively. On Mars, aerobic $\mathrm{Fe}^{2+}$ oxidation can achieve the maximum energy of $1.54 \mathrm{~J} / \mathrm{kg}$ mixed fluid at a lake water-to-groundwater ratio of 20 in the case of $\mathrm{Fe}^{2+}$-oxidizing magnetite formation. This energy value does not significantly change even if the $\mathrm{Fe}^{2+}$ in groundwater is increased to $1.04 \mathrm{mmol} / \mathrm{kg}$ (maximum energy: $1.55 \mathrm{~J} / \mathrm{kg}$ mixed fluid, Figure A3) or decreased to $0.024 \mathrm{mmol} / \mathrm{kg}$ (maximum energy: $0.92 \mathrm{~J} / \mathrm{kg}$ mixed fluid, Figure A3). The results suggest that ca. $1.5 \mathrm{~J} / \mathrm{kg}$ mixed fluid is the maximum energy available at fluid mixing zone on Mars. In contrast, the maximum energy obtained from the fluid-mixing zone on Earth is $48 \mathrm{~J} / \mathrm{kg}$ mixed fluid, which is 32 times that on Mars. This is mainly because the assumed Martian $p \mathrm{O}_{2}$ in this study ( 2 mbar) is two orders of magnitude lower than that on Earth, resulting in the much lower concentration of limiting reactant $\left(\mathrm{O}_{2}\right)$ of the metabolic reaction on Mars. These results suggest that fluid-mixing zone on Mars cannot provide as much energy as on Earth. However, the area with maximum free energy does not necessarily correspond to the areas actually inhabited by aerobic $\mathrm{Fe}^{2+}$-oxidizing microbes. Aerobic $\mathrm{Fe}^{2+}$-oxidizing bacteria prefer microaerophilic conditions $\left(\mathrm{O}_{2}(\mathrm{aq})\right.$ below $\left.10 \mu \mathrm{M}\right)$ because they compete with kinetically-fast abiotic oxidation of $\mathrm{Fe}^{2+}[62,68]$. In the Budo-pond in Hiroshima, indeed, the bioavailable energy at the fluid mixing ratio where $\mathrm{O}_{2}(\mathrm{aq})$ concentration is around $10 \mu \mathrm{M}$ was estimated to be $5.6 \mathrm{~J} / \mathrm{kg}$ mixed fluid when $\mathrm{Fe}^{2+}$-oxidizing goethite formation is considered (blue dotted line in Figure $7 \mathrm{~b}$ ), which is comparable to those calculated for a seawater-hydrothermal fluid-mixing zone actually inhabited by aerobic $\mathrm{Fe}^{2+}$-oxidizing microbes [21]. The calculated bioavailable energy on Earth is similar to that on Mars (1.5 J/kg mixed fluid) in the order of magnitude. Therefore, the fluid-mixing zone on early Mars may have had the potential to provide sufficient energy for aerobic $\mathrm{Fe}^{2+}$-oxidizing microbes. 
(a)

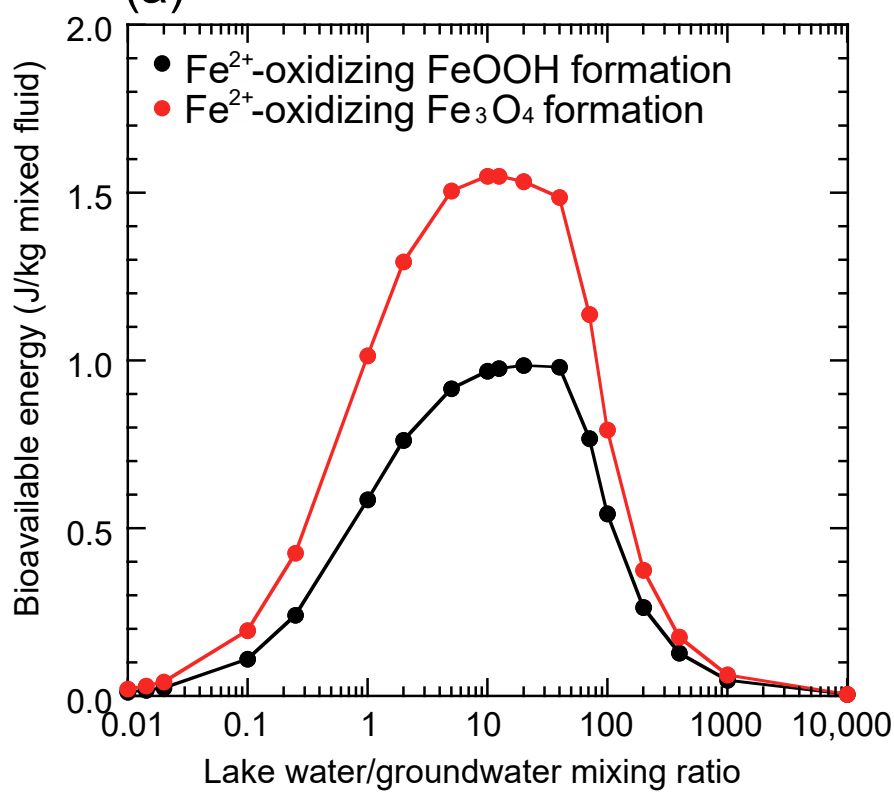

(b)

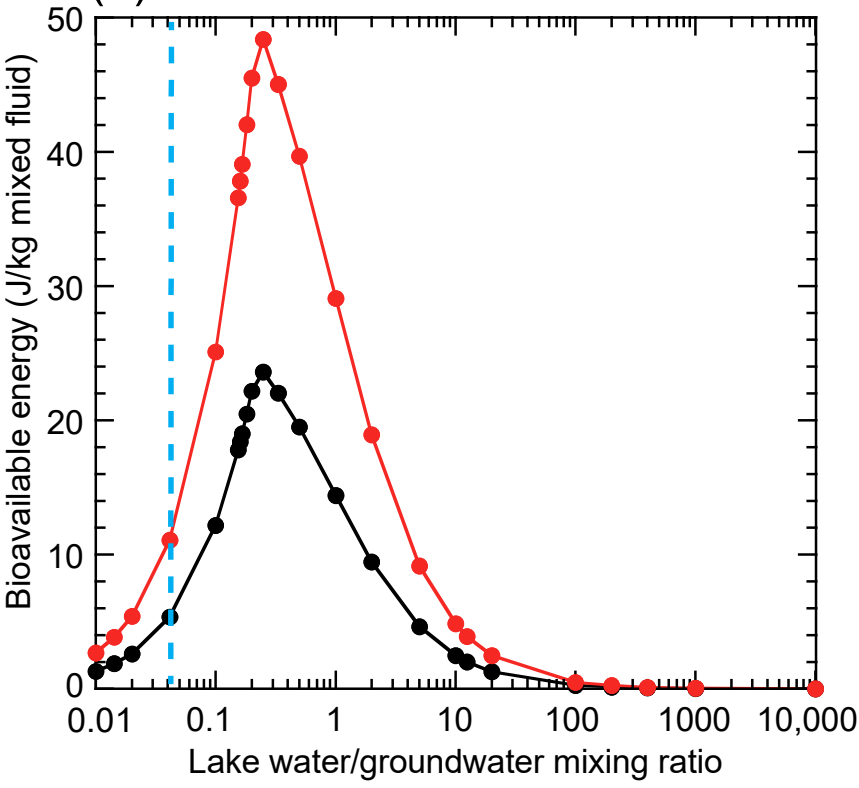

Figure 7. Bioavailable energy ( $/ \mathrm{kg}$ mixed fluid) from aerobic $\mathrm{Fe}^{2+}$-oxidizing goethite and magnetite formation as a function of surface water and groundwater water mixing ratio (a) on Mars and (b) on Earth (Budo-pond, Hiroshima, Japan). The blue dotted line in (b) highlights the fluid mixing zone actually inhabited by aerobic $\mathrm{Fe}^{2+}$-oxidizing microbes.

Next, we discuss the total bioavailable energy per kilogram of groundwater that has a positive correlation with the biomass potential sustained in the mixing zone. The maximum potential energy availability on Mars is about $82 \mathrm{~J} / \mathrm{kg}$ of groundwater at a lake water-togroundwater ratio of 70 in the case of $\mathrm{Fe}^{2+}$-oxidizing magnetite formation (Figure 8 ). This maximum bioavailable energy is higher than that in terrestrial groundwater discharge zone (Budo pond, Japan, Figure 8). Therefore, potential microbial abundance in Gale crater may have been similar to or slightly higher than that in the terrestrial on-land pond if groundwater influx is also identical to each other. In terrestrial seafloor hydrothermal systems, the available energies of most metabolic reactions were much higher than the maximum potential energy availability on Mars. For example, energy available from aerobic $\mathrm{Fe}^{2+}$ oxidation in the peridotite-hosted hydrothermal vent system (Rainbow) was estimated to be approximately $2000 \mathrm{~J} / \mathrm{kg}$ vent fluid at low-temperatures $\left(\sim 5^{\circ} \mathrm{C}\right)$ [19]. In basalt-hosted systems, the sulfide oxidation shows the highest available energy with a value of $\sim 5700 \mathrm{~J} / \mathrm{kg}$ vent fluid $\left(\sim 5^{\circ} \mathrm{C}\right)$ among major metabolic reactions [19]. Accordingly, the potential microbial abundances in Gale crater may have been much lower than those in terrestrial seafloor hydrothermal systems.

To understand the dependence of bioavailable energy on $p \mathrm{O}_{2}$, we additionally consider 20 mbar, 0.2 mbar, and 0.01 mbar of $p \mathrm{O}_{2}$. The assumed $\mathrm{W} / \mathrm{R}$ of water-rock reactions that generate lake water and groundwater are the same as those considered for the case of 2 mbar $p \mathrm{O}_{2}$ (3000 and 1000, respectively). As a result, the maximum bioavailable energies were estimated to be 15.4, 1.5, 0.15, and $0.007 \mathrm{~J} / \mathrm{kg}$ mixed fluid at $\mathrm{pO}_{2}$ of $20 \mathrm{mbar}, 2 \mathrm{mbar}$, 0.2 mbar, and 0.01 mbar, respectively (Figure A4 in Appendix A). The results suggest a decrease of bioavailable energy with decreasing $\mathrm{pO}_{2}$. Because the bioavailable energies on Earth where aerobic $\mathrm{Fe}^{2+}$-oxidizing microbes are actually living are in the order of several $\mathrm{J} / \mathrm{kg}$ mixed fluid as discussed in the previous section, at least a few mbar of $\mathrm{O}_{2}$ level may be required for sustaining microbial activity of $\mathrm{Fe}^{2+}$-oxidizing microbes on early Mars. 


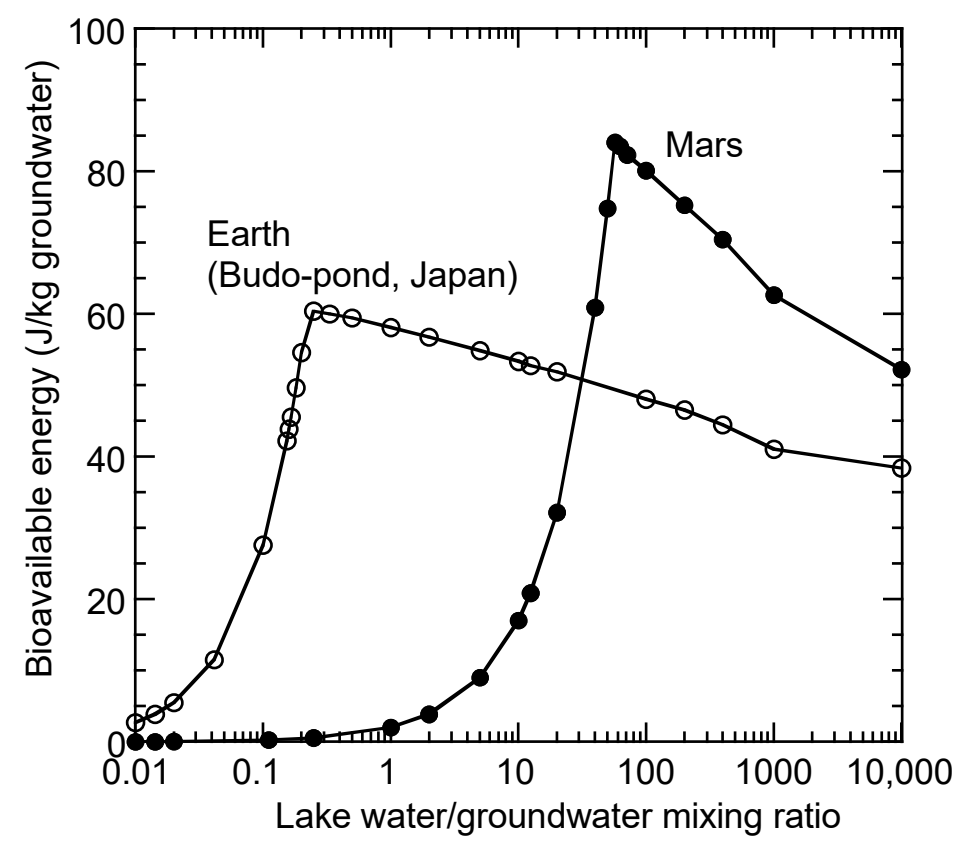

Figure 8. Bioavailable energy ( $/ / \mathrm{kg}$ groundwater) of aerobic $\mathrm{Fe}^{2+}$-oxidizing magnetite formation as a function of surface water-to-groundwater mixing ratio.

Although the calculations of bioavailable free energies focused on aerobic $\mathrm{Fe}^{2+}$ oxidizing microbes in this study, there are many other candidate metabolic reactions for early Mars (e.g., aerobic $S$ oxidizing microbes, methanogens, and Mn-oxidizing microbes). Further studies considering other redox reactions and various geological settings on Mars will provide a more comprehensive view of energetics-based Mars habitability, which may answer questions about not only the metabolic reactions that yield the largest bioavailable energy on early Mars but also the location and mineral that is the best target for detecting evidence of microbial life on Mars.

Author Contributions: Conceptualization, S.K. and T.S.; thermodynamic calculations, S.K.; writingoriginal draft preparation, S.K.; writing - review and editing, T.S.; funding acquisition, S.K. and T.S. All authors have read and agreed to the published version of the manuscript.

Funding: This research was funded by Grants-in-aid for Scientific Research, KAKENHI JSPS (grant numbers JP17H06455, JP17H06454, and JP18K14172).

Data Availability Statement: The data presented in this study are available on request from the corresponding author.

Acknowledgments: We thank Keisuke Fukushi for providing thermodynamic parameters of smectite.

Conflicts of Interest: The authors declare no conflict of interest. 


\section{Appendix A}

Table A1. Phases considered in the water-rock reaction modeling.

\begin{tabular}{|c|c|}
\hline Phase & Chemical Formula \\
\hline Alunite & $\mathrm{KAl}_{3}(\mathrm{OH})_{6}\left(\mathrm{SO}_{4}\right)_{2}$ \\
\hline Anhydrite & $\mathrm{CaSO}_{4}$ \\
\hline Aragonite & $\mathrm{CaCO}_{3}$ \\
\hline Artinite & $\mathrm{Mg}_{2} \mathrm{CO}_{3}(\mathrm{OH})_{2} \cdot 3 \mathrm{H}_{2} \mathrm{O}$ \\
\hline Bernalite & $\mathrm{Fe}(\mathrm{OH})_{3}$ \\
\hline Boehmite & $\mathrm{AlO}(\mathrm{OH})$ \\
\hline Brucite & $\mathrm{Mg}(\mathrm{OH})_{2}$ \\
\hline Ca-beidellite & $\mathrm{Ca}_{0.175} \mathrm{Al}_{2.35} \mathrm{Si}_{3.65} \mathrm{O}_{10}(\mathrm{OH})_{2}$ \\
\hline Ca-Fe-saponite & $\mathrm{Ca}_{0.175} \mathrm{Fe}_{3} \mathrm{Al}_{0.35} \mathrm{Si}_{3.65} \mathrm{O}_{10}(\mathrm{OH})_{2}$ \\
\hline Ca-montmorillonite & $\mathrm{Ca}_{0.175} \mathrm{Mg}_{0.35} \mathrm{Al}_{1.65} \mathrm{Si}_{4} \mathrm{O}_{10}(\mathrm{OH})_{2}$ \\
\hline Ca-nontronite & $\mathrm{Ca}_{0.175} \mathrm{Fe}_{2} \mathrm{Al}_{0.35} \mathrm{Si}_{3.65} \mathrm{O}_{10}(\mathrm{OH})_{2}$ \\
\hline Ca-saponite & $\mathrm{Ca}_{0.175} \mathrm{Mg}_{3} \mathrm{Al}_{0.35} \mathrm{Si}_{3.65} \mathrm{O}_{10}(\mathrm{OH})_{2}$ \\
\hline Calcite & $\mathrm{CaCO}_{3}$ \\
\hline Chalcedony & $\mathrm{SiO}_{2}$ \\
\hline Chrysotile & $\mathrm{Mg}_{3} \mathrm{Si}_{2} \mathrm{O}_{5}(\mathrm{OH})_{4}$ \\
\hline Cristobalite & $\mathrm{SiO}_{2}$ \\
\hline Diaspore & $\mathrm{AlHO}_{2}$ \\
\hline $\mathrm{Fe}(\mathrm{OH})_{2}$ & $\mathrm{Fe}(\mathrm{OH})_{2}$ \\
\hline $\mathrm{Fe}^{++}$-beidellite & $\mathrm{Fe}_{0.175} \mathrm{Al}_{2.35} \mathrm{Si}_{3.65} \mathrm{O}_{10}(\mathrm{OH})_{2}$ \\
\hline $\mathrm{Fe}^{++}$-Fe-saponite & $\mathrm{Fe}_{3.175} \mathrm{Al}_{0.35} \mathrm{Si}_{3.65} \mathrm{O}_{10}(\mathrm{OH})_{2}$ \\
\hline $\mathrm{Fe}^{++}$-montmorillonite & $\mathrm{Fe}_{0.175} \mathrm{Mg}_{0.35} \mathrm{Al}_{1.65} \mathrm{Si}_{4} \mathrm{O}_{10}(\mathrm{OH})_{2}$ \\
\hline $\mathrm{Fe}^{++}$-nontronite & $\mathrm{Fe}_{2.175} \mathrm{Al}_{0.35} \mathrm{Si}_{3.65} \mathrm{O}_{10}(\mathrm{OH})_{2}$ \\
\hline $\mathrm{Fe}^{++}$-saponite & $\mathrm{Fe}_{0.175} \mathrm{Mg}_{3} \mathrm{Al}_{0.35} \mathrm{Si}_{3.65} \mathrm{O}_{10}(\mathrm{OH})_{2}$ \\
\hline Gibbsite & $\mathrm{Al}(\mathrm{OH})_{3}$ \\
\hline Goethite & $\mathrm{FeOOH}$ \\
\hline Greenalite & $\mathrm{Fe}_{3} \mathrm{Si}_{2} \mathrm{O}_{5}(\mathrm{OH})_{4}$ \\
\hline Halite & $\mathrm{NaCl}$ \\
\hline Hematite & $\mathrm{Fe}_{2} \mathrm{O}_{3}$ \\
\hline Huntite & $\mathrm{CaMg}_{3}\left(\mathrm{CO}_{3}\right)_{4}$ \\
\hline Hydromagnesite & $\mathrm{Mg}_{5}(\mathrm{OH})_{2}\left(\mathrm{CO}_{3}\right)_{4} \cdot 4 \mathrm{H}_{2} \mathrm{O}$ \\
\hline K-beidellite & $\mathrm{K}_{0.35} \mathrm{Al}_{2.35} \mathrm{Si}_{3.65} \mathrm{O}_{10}(\mathrm{OH})_{2}$ \\
\hline K-Fe-saponite & $\mathrm{K}_{0.35} \mathrm{Fe}_{3} \mathrm{Al}_{0.35} \mathrm{Si}_{3.65} \mathrm{O}_{10}(\mathrm{OH})_{2}$ \\
\hline K-montmorillonite & $\mathrm{K}_{0.35} \mathrm{Mg}_{0.35} \mathrm{Al}_{1.65} \mathrm{Si}_{4} \mathrm{O}_{10}(\mathrm{OH})_{2}$ \\
\hline K-nontronite & $\mathrm{K}_{0.35} \mathrm{Fe}_{2} \mathrm{Al}_{0.35} \mathrm{Si}_{3.65} \mathrm{O}_{10}(\mathrm{OH})_{2}$ \\
\hline K-saponite & $\mathrm{K}_{0.35} \mathrm{Mg}_{3} \mathrm{Al}_{0.35} \mathrm{Si}_{3.65} \mathrm{O}_{10}(\mathrm{OH})_{2}$ \\
\hline Kaolinite & $\mathrm{Al}_{2} \mathrm{Si}_{2} \mathrm{O}_{5}(\mathrm{OH})_{4}$ \\
\hline Magnesite & $\mathrm{MgCO}_{3}$ \\
\hline Magnetite & $\mathrm{Fe}_{3} \mathrm{O}_{4}$ \\
\hline Mg-beidellite & $\mathrm{Mg}_{0.175} \mathrm{Al}_{2.35} \mathrm{Si}_{3.65} \mathrm{O}_{10}(\mathrm{OH})_{2}$ \\
\hline Mg-Fe-saponite & $\mathrm{Mg}_{0.175} \mathrm{Fe}_{3} \mathrm{Al}_{0.35} \mathrm{Si}_{3.65} \mathrm{O}_{10}(\mathrm{OH})_{2}$ \\
\hline Mg-montmorillonite & $\mathrm{Mg}_{0.525} \mathrm{Al}_{1.65} \mathrm{Si}_{4} \mathrm{O}_{10}(\mathrm{OH})_{2}$ \\
\hline Mg-nontronite & $\mathrm{Mg}_{0.175} \mathrm{Fe}_{2} \mathrm{Al}_{0.35} \mathrm{Si}_{3.65} \mathrm{O}_{10}(\mathrm{OH})_{2}$ \\
\hline Mg-saponite & $\mathrm{Mg}_{3.175} \mathrm{Al}_{0.35} \mathrm{Si}_{3.65} \mathrm{O}_{10}(\mathrm{OH})_{2}$ \\
\hline Na-beidellite & $\mathrm{Na}_{0.35} \mathrm{Al}_{2.35} \mathrm{Si}_{3.65} \mathrm{O}_{10}(\mathrm{OH})_{2}$ \\
\hline Na-Fe-saponite & $\mathrm{Na}_{0.35} \mathrm{Fe}_{3} \mathrm{Al}_{0.35} \mathrm{Si}_{3.65} \mathrm{O}_{10}(\mathrm{OH})_{2}$ \\
\hline Na-montmorillonite & $\mathrm{Na}_{0.35} \mathrm{Mg}_{0.35} \mathrm{Al}_{1.65} \mathrm{Si}_{4} \mathrm{O}_{10}(\mathrm{OH})_{2}$ \\
\hline Na-nontronite & $\mathrm{Na}_{0.35} \mathrm{Fe}_{2} \mathrm{Al}_{0.35} \mathrm{Si}_{3.65} \mathrm{O}_{10}(\mathrm{OH})_{2}$ \\
\hline Na-saponite & $\mathrm{Na}_{0.35} \mathrm{Mg}_{3} \mathrm{Al}_{0.35} \mathrm{Si}_{3.65} \mathrm{O}_{10}(\mathrm{OH})_{2}$ \\
\hline Portlandite & $\mathrm{Ca}(\mathrm{OH})_{2}$ \\
\hline Pyrite & $\mathrm{FeS}_{2}$ \\
\hline Pyrrhotite & $\mathrm{FeS}$ \\
\hline Quartz & $\mathrm{SiO}_{2}$ \\
\hline Sepiolite & $\mathrm{Mg}_{4} \mathrm{Si}_{6} \mathrm{O}_{15}(\mathrm{OH})_{2}\left(\mathrm{H}_{2} \mathrm{O}\right)_{2} \cdot 4 \mathrm{H}_{2} \mathrm{O}$ \\
\hline Siderite & $\mathrm{FeCO}_{3}$ \\
\hline Sillimanite & $\mathrm{Al}_{2} \mathrm{SiO}_{5}$ \\
\hline $\mathrm{SiO}_{2}$ (amorphous) & $\mathrm{SiO}_{2}$ \\
\hline Sulfur & S \\
\hline
\end{tabular}




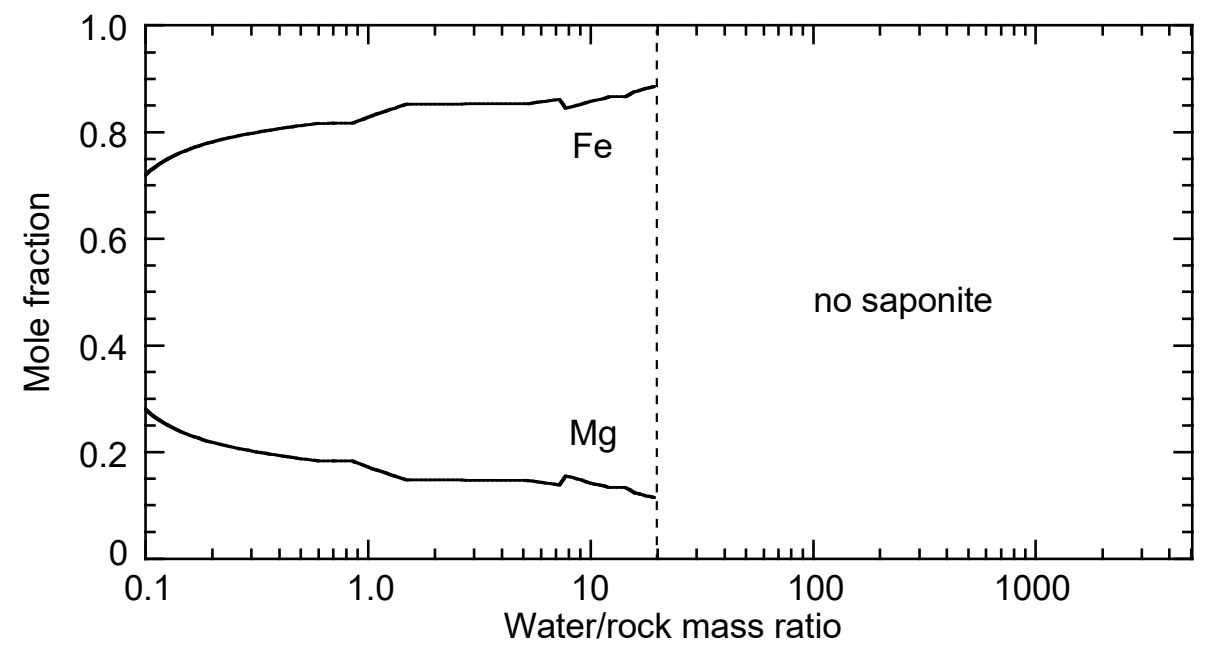

Figure A1. Mole fractions of saponite as a function of water-to-mass ratio when rock reacted with $\mathrm{O}_{2}$-bearing initial fluid (Case I-SG) at $5{ }^{\circ} \mathrm{C}$.

(a)

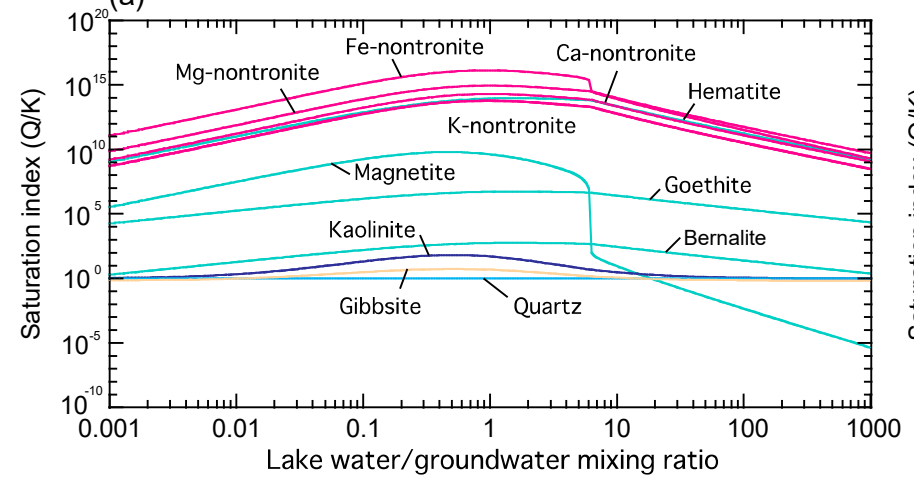

(b)

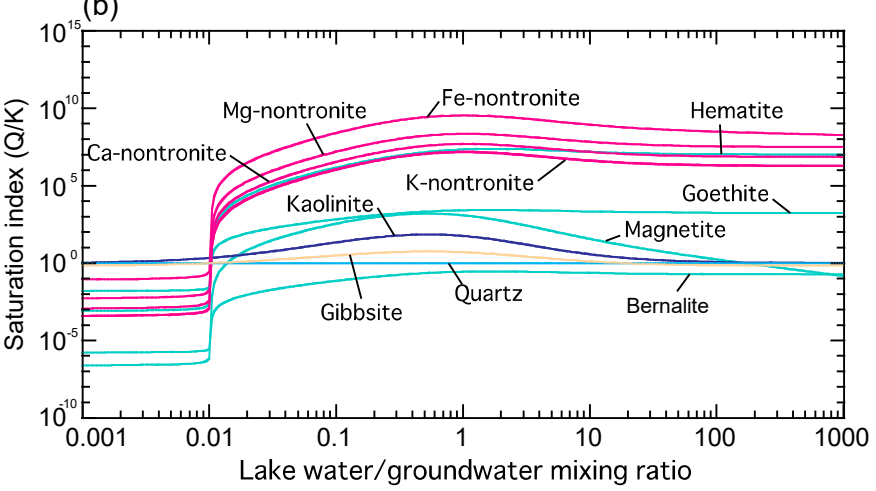

Figure A2. Mineral saturation indices when lake water and groundwater mixed under various lake water-to-groundwater mixing ratio at $p \mathrm{O}_{2}$ of (a) 20 mbar and (b) 0.01 mbar.

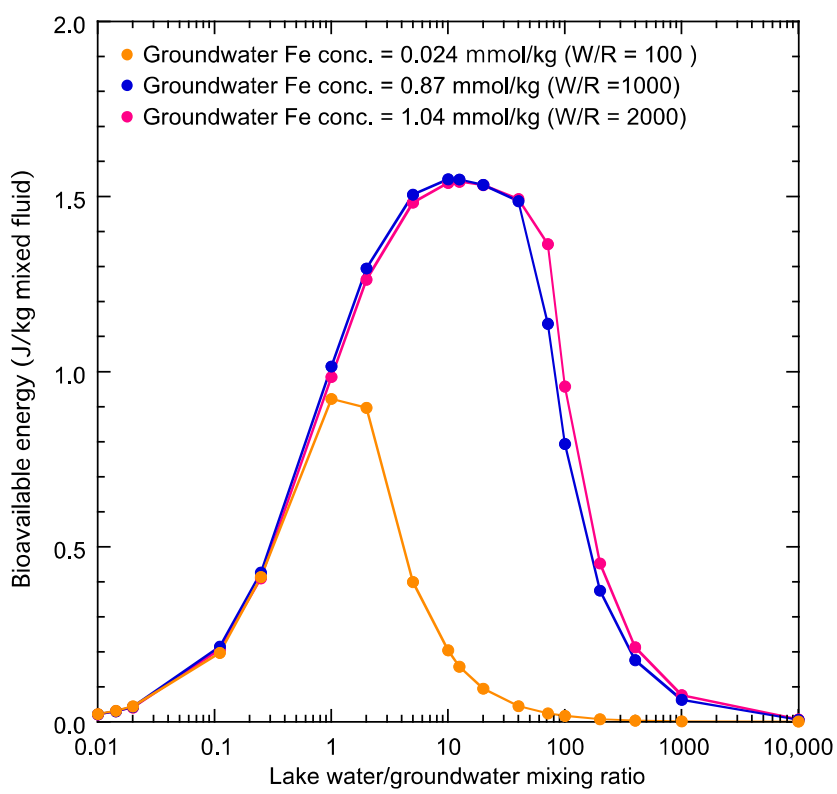

Figure A3. Bioavailable energy ( $/ \mathrm{kg}$ mixed fluid) from aerobic $\mathrm{Fe}^{2+}$-oxidizing magnetite formation at different groundwater chemistries $\left(\mathrm{Fe}^{2+}=1.04,0.87,0.024 \mathrm{mmol} / \mathrm{kg}\right)$. 


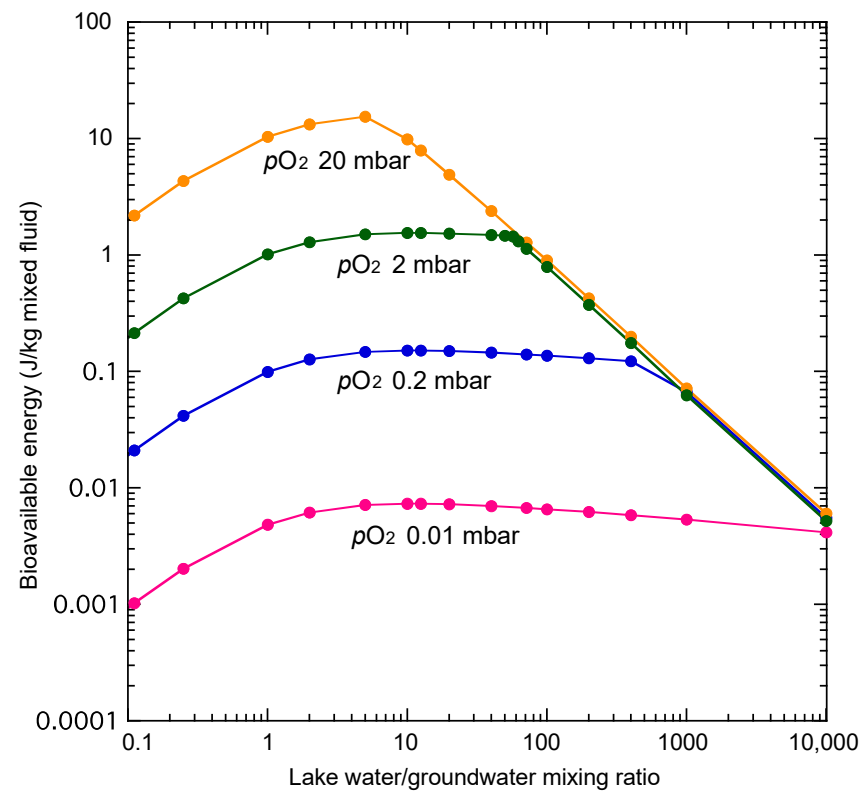

Figure A4. Bioavailable energy (J/kg mixed fluid) from aerobic $\mathrm{Fe}^{2+}$-oxidizing magnetite formation at $\mathrm{O}_{2}$ of $0.01,0.2,2$, and 20 mbar.

\section{References}

1. Fassett, C.I.; Head, J.W. The timing of martian valley network activity: Constraints from buffered crater counting. Icarus 2008, 195, 61-89. [CrossRef]

2. $\quad$ Ehlmann, B.L.; Mustard, J.F.; Murchie, S.L.; Bibring, J.P.; Meunier, A.; Fraeman, A.A.; Langevin, Y. Subsurface water and clay mineral formation during the early history of Mars. Nature 2011, 479, 53-60. [CrossRef] [PubMed]

3. Grotzinger, J.P.; Sumner, D.Y.; Kah, L.C.; Stack, K.; Gupta, S.; Edgar, L.; Rubin, D.; Lewis, K.; Schieber, J.; Mangold, N.; et al. A habitable fluvio-lacustrine environment at Yellowknife Bay, Gale crater, Mars. Science 2014, 343, 1242777. [CrossRef] [PubMed]

4. Hurowitz, J.A.; Grotzinger, J.P.; Fischer, W.W.; McLennan, S.M.; Milliken, R.E.; Stein, N.; Vasavada, A.R.; Blake, D.F.; Dehouck, E.; Eigenbrode, J.L.; et al. Redox stratification of an ancient lake in Gale crater, Mars. Science 2017, 356, eaah6849. [CrossRef] [PubMed]

5. Vaniman, D.T.; Bish, D.L.; Ming, D.W.; Bristow, T.F.; Morris, R.V.; Blake, D.F.; Chipera, S.J.; Morrison, S.M.; Treiman, A.H.; Rampe, E.B.; et al. Mineralogy of a mudstone at Yellowknife Bay, Gale Crater, Mars. Science 2014, 343, 1243480. [CrossRef]

6. Freissinet, C.; Glavin, D.P.; Mahaffy, P.R.; Miller, K.E.; Eigenbrode, J.L.; Summons, R.E.; Brunner, A.E.; Buch, A.; Szopa, C.; Archer, P.D.; et al. Organic molecules in the Sheepbed Mudstone, Gale Crater, Mars. J. Geophys. Res. Planets 2015, 120, 495-514. [CrossRef]

7. Nixon, S.; Cousins, C.R.; Cockell, C. Plausible microbial metabolisms on Mars. Astron. Geophys. 2013, 54, 13-16. [CrossRef]

8. Price, A.; Pearson, V.K.; Schwenzer, S.P.; Miot, J.; Olsson-Francis, K. Nitrate-dependent iron oxidation: A potential Mars metabolism. Front. Microbiol. 2018, 9, 513. [CrossRef]

9. Tung, H.C.; Bramall, N.E.; Price, P.B. Microbial origin of excess methane in glacial ice and implications for life on Mars. Proc. Natl. Acad. Sci. USA 2005, 102, 18292-18296. [CrossRef]

10. Macey, M.C.; Fox-Powell, M.; Ramkissoon, N.K.; Stephens, B.P.; Barton, T.; Schwenzer, S.P.; Pearson, V.K.; Cousins, C.R.; OlssonFrancis, K. The identification of sulfide oxidation as a potential metabolism driving primary production on late Noachian Mars. Sci. Rep. 2020, 10, 10941. [CrossRef]

11. King, G.M. Carbon monoxide as a metabolic energy source for extremely halophilic microbes: Implications for microbial activity in Mars regolith. Proc. Natl. Acad. Sci. USA 2015, 112, 4465-4470. [CrossRef] [PubMed]

12. Curtis-Harper, E.; Pearson, V.K.; Summers, S.; Bridges, J.C.; Schwenzer, S.P.; Olsson-Francis, K. The microbial community of a terrestrial anoxic inter-tidal zone: A model for laboratory-based studies of potentially habitable ancient lacustrine systems on Mars. Microorganisms 2018, 6, 61. [CrossRef] [PubMed]

13. Cousins, C. Volcanogenic fluvial-lacustrine environments in Iceland and their utility for identifying past habitability on Mars. Life 2015, 5, 568-586. [CrossRef] [PubMed]

14. Amils, R.; González-Toril, E.; Fernández-Remolar, D.; Gómez, F.; Aguilera, Á.; Rodríguez, N.; Malki, M.; García-Moyano, A.; Fairén, A.G.; de la Fuente, V.; et al. Extreme environments as Mars terrestrial analogs: The Rio Tinto case. Planet. Space Sci. 2007, 55, 370-381. [CrossRef]

15. Gronstal, A.; Pearson, V.; Kappler, A.; Dooris, C.; Anand, M.; Poitrasson, F.; Kee, T.P.; Cockell, C.S. Laboratory experiments on the weathering of iron meteorites and carbonaceous chondrites by iron-oxidizing bacteria. Meteorit. Planet. Sci. 2009, 44, 233-247. [CrossRef] 
16. Oren, A.; Elevi Bardavid, R.; Mana, L. Perchlorate and halophilic prokaryotes: Implications for possible halophilic life on Mars. Extremophiles 2014, 18, 75-80. [CrossRef]

17. Fukushi, K.; Sekine, Y.; Sakuma, H.; Morida, K.; Wordsworth, R. Semiarid climate and hyposaline lake on early Mars inferred from reconstructed water chemistry at Gale. Nat. Commun. 2019, 10, 4896. [CrossRef]

18. McCollom, T.M.; Shock, E.L. Geochemical constraints on chemolithoautotrophic metabolism by microorganisms in seafloor hydrothermal systems. Geochim. Cosmochim. Acta 1997, 61, 4375-4391. [CrossRef]

19. Amend, J.P.; McCollom, T.M.; Hentscher, M.; Bach, W. Catabolic and anabolic energy for chemolithoautotrophs in deep-sea hydrothermal systems hosted in different rock types. Geochim. Cosmochim. Acta 2011, 75, 5736-5748. [CrossRef]

20. McCollom, T.M.; Amend, J.P. A thermodynamic assessment of energy requirements for biomass synthesis by chemolithoautotrophic micro-organisms in oxic and anoxic environments. Geobiology 2005, 3, 135-144. [CrossRef]

21. Kato, S.; Nakamura, K.; Toki, T.; Ishibashi, J.; Tsunogai, U.; Hirota, A.; Ohkuma, M.; Yamagishi, A. Iron-based microbial ecosystem on and below the seafloor: A case study of hydrothermal fields of the southern mariana trough. Front. Microbiol. $2012,3,89$. [CrossRef]

22. Takai, K.; Nakamura, K. Archaeal diversity and community development in deep-sea hydrothermal vents. Curr. Opin. Microbiol. 2011, 14, 282-291. [CrossRef] [PubMed]

23. McLennan, S.M.; Anderson, R.B.; Bell, J.F.; Bridges, J.C.; Calef, F.; Campbell, J.L.; Clark, B.C.; Clegg, S.; Conrad, P.; Cousin, A.; et al. Elemental geochemistry of sedimentary rocks at Yellowknife Bay, Gale Crater, Mars. Science 2014, 343, 1244734. [CrossRef] [PubMed]

24. Bristow, T.F.; Bish, D.L.; Vaniman, D.T.; Morris, R.V.; Blake, D.F.; Grotzinger, J.P.; Rampe, E.B.; Crisp, J.A.; Achilles, C.N.; Ming, D.W.; et al. The origin and implications of clay minerals from Yellowknife Bay, Gale crater, Mars. Am. Miner. 2015, 100, 824-836. [CrossRef]

25. Mangold, N.; Thompson, L.M.; Forni, O.; Williams, A.J.; Fabre, C.; Le Deit, L.; Wiens, R.C.; Williams, R.; Anderson, R.B.; Blaney, D.L.; et al. Composition of conglomerates analyzed by the Curiosity rover: Implications for Gale Crater crust and sediment sources. J. Geophys. Res. Planets 2016, 121, 353-387. [CrossRef]

26. Jugo, P.J. An experimental study of the sulfur content in basaltic melts saturated with immiscible sulfide or sulfate liquids at 1300 ${ }^{\circ} \mathrm{C}$ and 1.0 GPa. J. Geophys. Res. Planets 2004, 46, 783-798. [CrossRef]

27. Carroll, M.R.; Webster, J.D. Solubilities of sulfur, noble gases, nitrogen, chlorine, and fluorine in magmas. Rev. Mineral. 1994, 30, 231-279. [CrossRef]

28. Zelenski, M.; Taran, Y. Volcanic emissions of molecular chlorine. Geochim. Cosmochim. Acta 2012, 87, 210-226. [CrossRef]

29. Kurokawa, H.; Kurosawa, K.; Usui, T. A lower limit of atmospheric pressure on early Mars inferred from nitrogen and argon isotopic compositions. Icarus 2018, 299, 443-459. [CrossRef]

30. Pollack, J.B.; Kasting, J.F.; Richardson, S.M.; Poliakoff, K. The case for a wet, warm climate on early Mars. Icarus 1987, 71, $203-224$. [CrossRef]

31. Owen, T. The composition of the Martian atmosphere. Adv. Space Res. 1982, 2, 75-80. [CrossRef]

32. Noda, N.; Imamura, S.; Sekine, Y.; Kurisu, M.; Fukushi, K.; Terada, N.; Uesugi, S.; Numako, C.; Takahashi, Y.; Hartmann, J. Highly oxidizing aqueous environments on early Mars inferred from scavenging pattern of trace metals on manganese oxides. J. Geophys. Res. Planets 2019, 124, 1282-1295. [CrossRef]

33. Lanza, N.L.; Wiens, R.C.; Arvidson, R.E.; Clark, B.C.; Fischer, W.W.; Gellert, R.; Grotzinger, J.P.; Hurowitz, J.A.; McLennan, S.M.; Morris, R.V.; et al. Oxidation of manganese in an ancient aquifer, Kimberley formation, Gale crater, Mars. Geophys. Res. Lett. 2016, 43, 7398-7407. [CrossRef]

34. Ramirez, R.M. A warmer and wetter solution for early Mars and the challenges with transient warming. Icarus 2017, $297,71-82$. [CrossRef]

35. Grotzinger, J.P.; Gupta, S.; Malin, M.C.; Rubin, D.M.; Schieber, J.; Siebach, K.; Sumner, D.Y.; Stack, K.M.; Vasavada, A.R.; Arvidson, R.E.; et al. Deposition, exhumation, and paleoclimate of an ancient lake deposit, Gale crater, Mars. Science 2015, $350,6257$. [CrossRef] [PubMed]

36. Schwenzer, S.P.; Abramov, O.; Allen, C.C.; Bridges, J.C.; Clifford, S.M.; Filiberto, J.; Kring, D.A.; Lasue, J.; McGovern, P.J.; Newsom, H.E.; et al. Gale Crater: Formation and post-impact hydrous environments. Planet. Space Sci. 2012, 70, 84-95. [CrossRef]

37. Wolery, T.; Jarek, R. Software User'S Manual EQ3/6 (Version 8.0); Sandia National Laboratories: Albuquerque, NM, USA, 2003.

38. Johnson, J.W.; Oelkers, E.H.; Helgeson, H.C. Supcrt92-A software package for calculating the standard molal thermodynamic properties of minerals, gases, aqueous species, and reactions from 1 to 5000 -bar and 0 to $1000^{\circ} \mathrm{C}$. Comput. Geosci. 1992, 18, 899-947. [CrossRef]

39. Shock, E.L.; Helgeson, H.C. Calculation of the thermodynamic and transport properties of aqueous species at high pressures and temperatures: Correlation algorithms for ionic species and equation of state predictions to $5 \mathrm{~kb}$ and $1000^{\circ} \mathrm{C}$. Geochim. Cosmochim. Acta 1988, 52, 2009-2036. [CrossRef]

40. Shock, E.L.; Koretsky, C.M. Metal-organic complexes in geochemical processes: Estimation of standard partial molal thermodynamic properties of aqueous complexes between metal-cations and monovalent organic-acid ligands at high-pressures and temperatures. Geochim. Cosmochim. Acta 1995, 59, 1497-1532. [CrossRef] 
41. Shock, E.L.; Helgeson, H.C.; Sverjensky, D.A. Calculation of the thermodynamic and transport-properties of aqueous species at high-pressures and temperatures: Standard partial molal properties of inorganic neutral species. Geochim. Cosmochim. Acta 1989, 53, 2157-2183. [CrossRef]

42. Majzlan, J.; Grevel, K.D.; Navrotsky, A. Thermodynamics of Fe oxides: Part II. Enthalpies of formation and relative stability of goethite $(\alpha-\mathrm{FeOOH})$, lepidocrocite $(\gamma-\mathrm{FeOOH})$, and maghemite $\left(\gamma-\mathrm{Fe}_{2} \mathrm{O}_{3}\right)$. Am. Miner. 2003, 88, 855-859. [CrossRef]

43. Majzlan, J.; Lang, B.E.; Stevens, R.; Navrotsky, A.; Woodfield, B.F.; Boerio-Goates, J. Thermodynamics of Fe oxides: Part I. Entropy at standard temperature and pressure and heat capacity of goethite $(\alpha-\mathrm{FeOOH})$, lepidocrocite $(\gamma-\mathrm{FeOOH})$, and maghemite $\left(\gamma-\mathrm{Fe}_{2} \mathrm{O}_{3}\right)$. Am. Miner. 2003, 88, 846-854. [CrossRef]

44. Wilson, J.; Savage, D.; Cuadros, J.; Shibata, M.; Ragnarsdottir, K.V. The effect of iron on montmorillonite stability. (I) Background and thermodynamic considerations. Geochim. Cosmochim. Acta 2006, 70, 306-322. [CrossRef]

45. Drummond, S. Boiling and Mixing of Hydrothermal Fluids: Chemical Effects on Mineral Precipitation. Ph.D. Thesis, The Pennsylvania State University, State College, PA, USA, 1982.

46. Zolotov, M.Y. Aqueous fluid composition in CI chondritic materials: Chemical equilibrium assessments in closed systems. Icarus 2012, 220, 713-729. [CrossRef]

47. Viennet, J.-C.; Bultel, B.; Riu, L.; Werner, S.C. Dioctahedral phyllosilicates versus zeolites and carbonates versus zeolites competitions as constraints to understanding early Mars alteration conditions. J. Geophys. Res. Planets 2017, 122, $2328-2343$. [CrossRef]

48. Treiman, A.H.; Morris, R.V.; Agresti, D.G.; Graff, T.G.; Achilles, C.N.; Rampe, E.B.; Bristow, T.F.; Ming, D.W.; Blake, D.F.; Vaniman, D.T.; et al. Ferrian saponite from the Santa Monica Mountains (California, U.S.A., Earth): Characterization as an analog for clay minerals on Mars with application to Yellowknife Bay in Gale Crater. Am. Miner. 2014, 99, 2234-2250. [CrossRef]

49. Chemtob, S.M.; Nickerson, R.D.; Morris, R.V.; Agresti, D.G.; Catalano, J.G. Oxidative alteration of ferrous smectites and implications for the redox evolution of early Mars. J. Geophys. Res. Planets 2017, 122, 2469-2488. [CrossRef]

50. Bridges, J.C.; Schwenzer, S.P.; Leveille, R.; Westall, F.; Wiens, R.C.; Mangold, N.; Bristow, T.; Edwards, P.; Berger, G. Diagenesis and clay mineral formation at Gale Crater, Mars. J. Geophys. Res. Planets 2015, 120, 1-19. [CrossRef] [PubMed]

51. Melwani Daswani, M.; Schwenzer, S.P.; Reed, M.H.; Wright, I.P.; Grady, M.M. Alteration minerals, fluids, and gases on early Mars: Predictions from 1-D flow geochemical modeling of mineral assemblages in meteorite ALH 84001. Meteorit. Planet. Sci. 2016, 51, 2154-2174. [CrossRef]

52. Schieber, J.; Bish, D.; Coleman, M.; Reed, M.; Hausrath, E.M.; Cosgrove, J.; Gupta, S.; Minitti, M.E.; Edgett, K.S.; Malin, M.; et al. Encounters with an unearthly mudstone: Understanding the first mudstone found on Mars. Sedimentology 2017, 64, 311-358. [CrossRef]

53. Ming, D.W.; Archer, P.; Glavin, D.; Eigenbrode, J.; Franz, H.; Sutter, B.; Brunner, A.; Stern, J.; Freissinet, C.; McAdam, A. Volatile and organic compositions of sedimentary rocks in Yellowknife Bay, Gale Crater, Mars. Science 2014, 343, 1245267. [CrossRef]

54. Michalski, J.R.; Cuadros, J.; Niles, P.B.; Parnell, J.; Deanne Rogers, A.; Wright, S.P. Groundwater activity on Mars and implications for a deep biosphere. Nat. Geosci. 2013, 6, 133-138. [CrossRef]

55. Cornell, R.M.; Schwertmann, U. The Iron Oxides: Structure, Properties, Reactions, Occurrences and Uses, 2nd ed.; Wiley-VCH: Weinheim, Germany, 2003.

56. Baum, M.; Wordsworth, R. Groundwater flow to Gale Crater in an episodically warm climate. J. Geophys. Res. Planets 2020, 125. [CrossRef]

57. Kawano, M.; Tomita, K. Microbial biomineralization in weathered volcanic ash deposit and formation of biogenic minerals by experimental incubation. Am. Miner. 2001, 86, 400-410. [CrossRef]

58. Chaffin, M.S.; Deighan, J.; Schneider, N.M.; Stewart, A.I.F. Elevated atmospheric escape of atomic hydrogen from Mars induced by high-altitude water. Nat. Geosci. 2017, 10, 174-178. [CrossRef]

59. Hurowitz, J.A.; Fischer, W.; Tosca, N.J.; Milliken, R.E. Origin of acidic surface waters and the evolution of atmospheric chemistry on early Mars. Nat. Geosci. 2010, 3, 323-326. [CrossRef]

60. Tosca, N.J.; Ahmed, I.A.M.; Tutolo, B.M.; Ashpitel, A.; Hurowitz, J.A. Magnetite authigenesis and the warming of early Mars. Nat. Geosci. 2018, 11, 635-639. [CrossRef]

61. Lupton, J.E. Hydrothermal plumes: Near and far field. Seafloor Hydrothermal Syst. Phys. Chem. Biol. Geol. Interact. 1995, 91, 317-346. [CrossRef]

62. Emerson, D.; Fleming, E.J.; McBeth, J.M. Iron-oxidizing bacteria: An environmental and genomic perspective. Annu. Rev. Microbiol. 2010, 64, 561-583. [CrossRef] [PubMed]

63. Edwards, K.J.; Bach, W.; McCollom, T.M.; Rogers, D.R. Neutrophilic iron-oxidizing bacteria in the ocean: Their habitats, diversity, and roles in mineral deposition, rock alteration, and biomass production in the deep-sea. Geomicrobiol. J. 2004, 21, 393-404. [CrossRef]

64. Kato, S.; Kikuchi, S.; Kashiwabara, T.; Takahashi, Y.; Suzuki, K.; Itoh, T.; Ohkuma, M.; Yamagishi, A. Prokaryotic abundance and community composition in a freshwater iron-rich microbial mat at circumneutral pH. Geomicrobiol. J. 2012, 29, 896-905. [CrossRef]

65. Kikuchi, S.; Makita, H.; Konno, U.; Shiraishi, F.; Ijiri, A.; Takai, K.; Maeda, M.; Takahashi, Y. Limited reduction of ferrihydrite encrusted by goethite in freshwater sediment. Geobiology 2016, 14, 374-389. [CrossRef] [PubMed]

66. Takahashi, Y.; Hirata, T.; Shimizu, H.; Ozaki, T.; Fortin, D. A rare earth element signature of bacteria in natural waters? Chem. Geol. 2007, 244, 569-583. [CrossRef] 
67. Kato, S.; Chan, C.; Itoh, T.; Ohkuma, M. Functional gene analysis of freshwater iron-rich flocs at circumneutral pH and isolation of a stalk-forming microaerophilic iron-oxidizing bacterium. Appl. Environ. Microbiol. 2013, 79, 5283-5290. [CrossRef] [PubMed]

68. Druschel, G.K.; Emerson, D.; Sutka, R.; Suchecki, P.; Luther, G.W. Low-oxygen and chemical kinetic constraints on the geochemical niche of neutrophilic iron(II) oxidizing microorganisms. Geochim. Cosmochim. Acta 2008, 72, 3358-3370. [CrossRef] 